\title{
Novel symmetric bis-benzimidazoles: synthesis, DNA/RNA binding and antitrypanosomal activity
}

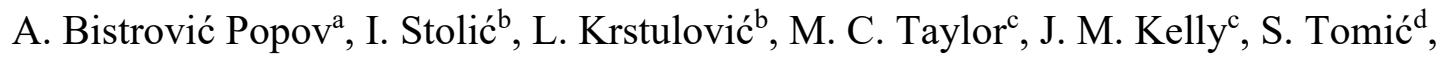 \\ M. Bajićc ${ }^{b}$ S. Raić-Malića ${ }^{{ }^{*}}$ \\ ${ }^{a}$ Department of Organic Chemistry, Faculty of Chemical Engineering and Technology, \\ University of Zagreb, Marulićev trg 20, HR-10000 Zagreb, Croatia \\ ${ }^{b}$ Department of Chemistry and Biochemistry, Faculty of Veterinary Medicine, University \\ of Zagreb, Heinzelova 55, HR-10000 Zagreb, Croatia \\ ${ }^{c}$ Department of Pathogen Molecular Biology, London School of Hygiene and Tropical \\ Medicine, Keppel Street, London, WC1E 7HT, UK \\ ${ }^{d}$ Division of Organic Chemistry and Biochemistry, Physical Chemistry, Ruđer Bošković \\ Institute, Bijenička 54, HR-10000 Zagreb, Croatia
}

*Corresponding Author:

Tel: 00385-1-4597-213, Fax: 00385-1-4597-224, E-mail: sraic@fkit.hr 


\begin{abstract}
The novel benzimidazol-2-yl-fur-5-yl-(1,2,3)-triazolyl dimeric series with aliphatic and aromatic central linkers was successfully prepared with the aim of assessing binding affinity to DNA/RNA and antitrypanosomal activity. UV-Visible spectroscopy, thermal denaturation and circular dichroism studies indicated strong and selective interaction of heterocyclic bis-amidines with $c t \mathrm{DNA}$ and revealed minor groove binding as the dominant binding mode. The amidino fragment and 1,4-bis(oxymethylene)phenyl spacer were the main determinants of activity against Trypanosoma brucei. The bisbenzimidazole imidazoline 15c, which had antitrypanosomal potency in the submicromolar range and DNA interacting properties, emerged as a candidate for further structural optimization to obtain more effective agents to combat trypanosome infections.
\end{abstract}

Keywords: bis-benzimidazoles, ctDNA binding, UV-Vis, CD spectroscopy, thermal denaturation, Trypanosoma brucei 


\section{Introduction}

Neglected tropical diseases (NTDs) affect more than 1 billion people, around $15 \%$ of the world's population [1]. Human African trypanosomiasis (HAT), or sleeping sickness, is one of the most deadly NTDs, with 65 million people at risk in 36 countries [1-4]. It is caused by two subspecies of the protozoan parasite Trypanosoma brucei, which are transmitted to humans through the bite of tsetse flies in sub-Saharan Africa.

Aromatic diamidines have had several applications in antiparasitic therapy, with well-known examples such as berenil and pentamidine [5-7]. Although the bisbenzamidine derivative, pentamidine (Figure 1), has been used clinically against trypanosomiasis for over 70 years [8-10] it is not effective when given orally, can cause severe toxicity, and is unable to kill parasites which have breached the blood-brain barrier during stage 2 HAT [10-12]. A related diamidine, berenil, is not currently used in humans, but it is important for control of animal trypanosomal diseases, which inflict a huge economic burden in sub-Saharan Africa [13]. Additionally, pafuramidine (DB289), which is the oral prodrug of furamidine (DB75) was recently evaluated in phase III clinical trials [14]. Unfortunately, these trials had to be discontinued due to hepatic and renal toxicity [15]. Although aromatic diamidines have been used in the treatment of protozoal diseases for many years, their precise mechanism of action is not fully understood. Various targets have been suggested, including both mitochondrial and nuclear DNA, microtubules, acidocalcisomes, and a range of enzymes [10,12,16-19].

Current therapies for HAT are unsatisfactory and under threat from emerging resistance, what is frequently linked to the activity of transporters responsible for drug uptake $[20,21]$. This has prompted the search of benzimidazole derivatives that are more efficacious for combating this fatal infection [22-25]. As an example, amidinobenzimidazoles have been developed as potent anti-trypanosomal agents [26-29]. Additionally, it has been shown that introduction of nitrogen atoms into the aromatic system of furamidine changes the lipophilicity and polarity of the heterocyclic core, generating aza analogs that may cross the blood brain barrier (Figure 1) [12,19,21]. Thus, diphenyl furan-based and aza analogs have been developed as candidates for treatment of second-stage HAT. Diamidines containing a 1,2,3-triazole ring as the central core were 
the first aromatic members of this class of molecule to show efficacy superior to that of melarsoprol [30].
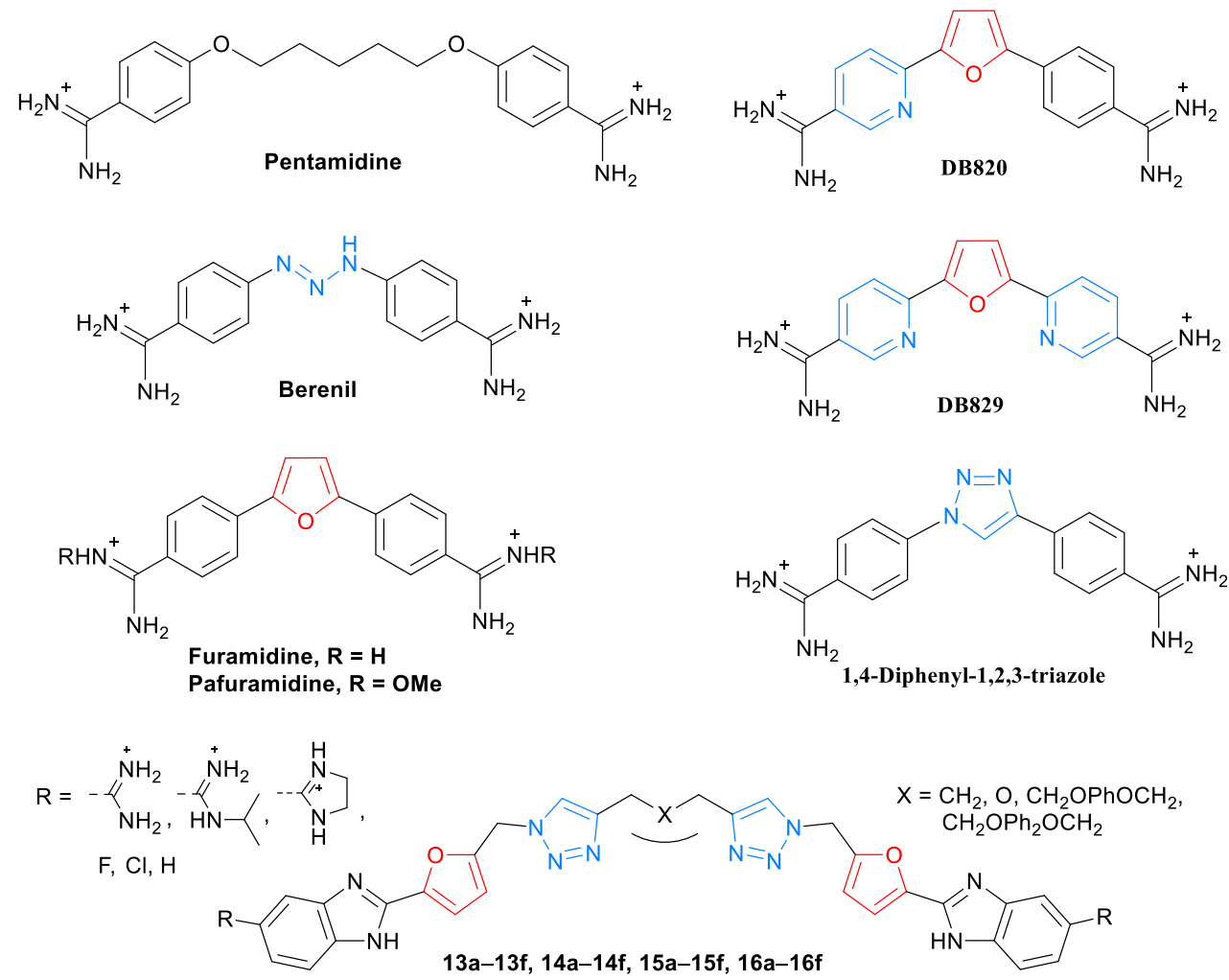

presented in this work

Fig. 1. Structure of compounds with potent antitrypanosomal activities and novel symmetric bis-benzimidazoles 13a-13f, 14a-14f, 15a-15f and 16a-16f.

Based on these studies, and in continuation of our recent work on the development of aromatic amidines as DNA-binding ligands [31,32] and anti-trypanosomal agents [33,34], we aimed here to expand the benzimidazole scaffold to 5-membered furyl and 1,2,3triazolyl moieties that may adopt helical topology to approximately match the curvature of DNA in the minor groove. Design strategy led to a symmetric series of bis(benzimidazol-2-yl-fur-5-yl-azole) derivatives connected via aliphatic and aromatic linkers (Figure 2). In this context, the influence of diverse linkers and the type of 5amidine and 5-halogen substituents in bis-benzimidazoles 13a-13f, 14a-14f, 15a-15f and 16a-16f on their DNA/RNA binding affinity and antiprotozoal activity has been explored. Here, we describe the synthesis of novel symmetric bis-benzimidazoles and 
their DNA/RNA binding affinities as assessed by UV-Vis and CD spectroscopy, as well as thermal denaturation experiments. Antitrypanosomal potencies of the novel compounds were evaluated and their structure-activity relationship (SAR) is discussed. To better understand the mode of DNA binding, we performed molecular modelling of the most potent trypanocidal compound $(\mathbf{1 5 c})$ when bound to the minor groove of DNA.

\section{Results and Discussion}

\subsection{Chemistry}

Synthesis of novel symmetric bis-[benzimidazol-2-yl-fur-5-yl-(1,2,3)-triazolyl] derivatives (13a-13f, 14a-14f, 15a-15f and 16a-16f) was carried out as outlined in Scheme 1. A one-pot route in biphasic mixture $\mathrm{HCl}-\mathrm{H}_{3} \mathrm{PO}_{4} / \mathrm{CHCl}_{3}$ was applied for efficient conversion of D-fructose (1) to 5-chloromethylfurfural (2), as described in literature [35,36], which then in reaction with sodium azide, gave rise to 5azidomethylfurfural (3). The key precursors, symmetric bis-triazolyl aldehydes connected through 1,3-propylene (8), oxydimethylene (9), 1,4-bis(oxymethylene)phenyl (10), 4,4'bis(oxymethylene)biphenyl (11) linkers were synthesized by $\mathrm{Cu}(\mathrm{I})$-catalyzed 1,3cycloaddition of the azide 3 with corresponding terminal bis-alkynes (4-7), using microwave irradiation. A click reaction produced bis-(1,2,3-triazolyl) aldehydes $\mathbf{1 0}$ and 11 linked through an aromatic spacer, with excellent yield (ca. 98\%), while bis-(1,2,3triazolyl) aldehydes 8 and $\mathbf{9}$ connected through an aliphatic chain were obtained in lower yield (ca. 36\%). Amidino-substituted $o$-phenylenediamines (12a-12c) were prepared by the Pinner method as previously reported in the literature [37]. Condensation of various $o$-phenylenediamines (12a-12f) with bis-(1,2,3-triazolyl) aldehydes (8-11) using $\mathrm{NaHSO}_{3}$ or $p$-benzoquinone, as an oxidative reagent, afforded the target bisbenzimidazole derivatives with 5 -amidino- (13a-13c, 14a-14c, 15a-15c and 16a-16c), 5-fluoro- (13d-16d) and 5-chloro-substituted (13e-16e), as well as non-substituted benzimidazoles (13f-16f). 


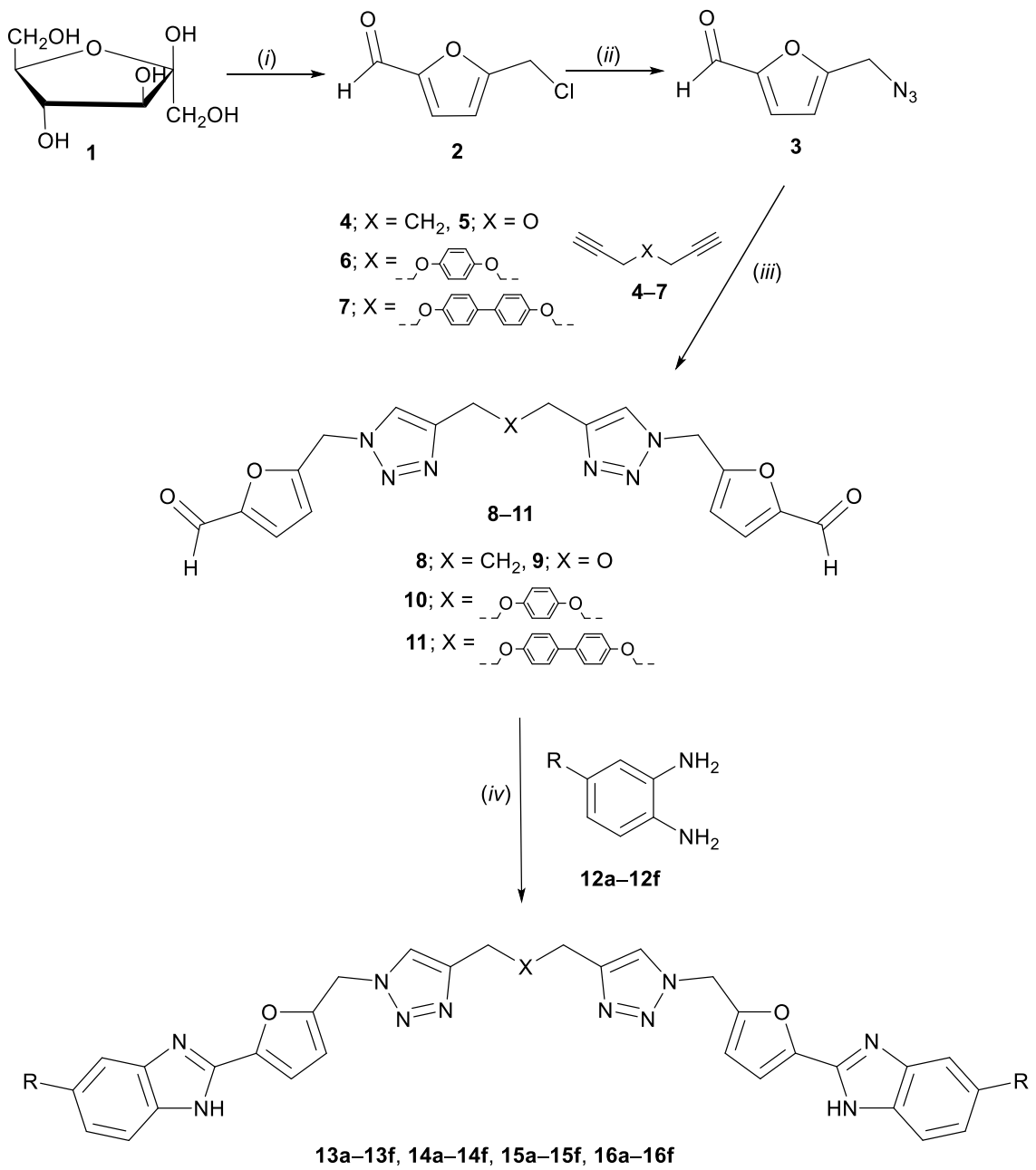

$13 a-13 f, 14 a-14 f, 15 a-15 f, 16 a-16 f$

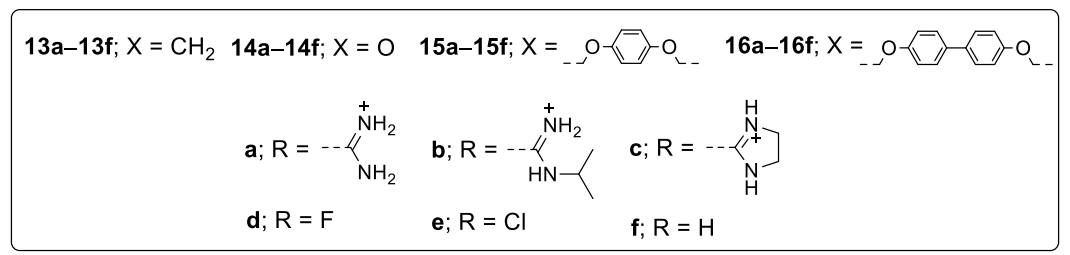

Scheme 1. Reagents and conditions: $(i) \mathrm{HCl}: \mathrm{H}_{3} \mathrm{PO}_{4}=4: 1, \mathrm{CCl}_{3}, 45{ }^{\circ} \mathrm{C}, 20 \mathrm{~h}$; (ii) $\mathrm{NaN}_{3}$, AcCN, reflux, $24 \mathrm{~h}$; (iii) terminal alkyne, $\mathrm{Cu}(0), \mathrm{CuSO}_{4}, t-\mathrm{BuOH}: \mathrm{H}_{2} \mathrm{O}=1$ : 1, DMF, MW, $300 \mathrm{~W}, 80^{\circ} \mathrm{C}, 1.5 \mathrm{~h}$; (iv) $\mathrm{NaHSO}_{3} / p$-benzoquinone, EtOH, reflux, 6 h.

\subsection{Spectroscopic characterization of novel bis-benzimidazoles}

The spectroscopic characterization of novel 5-amidino- and 5-halogen-substituted benzimidazoles (13a-13f, 14a-14f, 15a-15f and 16a-16f) was explored by UV-Vis spectroscopy. Absorption maxima and the corresponding molar extinction coefficients $(\varepsilon)$ 
are given in Table S1 (Supplementary Information). The changes of the UV-VIS spectra when the temperature was raised to $95^{\circ} \mathrm{C}$ were negligible, and the reproducibility of UVVis spectra upon cooling back to $25{ }^{\circ} \mathrm{C}$ was excellent. Solutions of the studied compounds were stable for many days at room temperature, confirming that all compounds were suitable for further biophysical and biological investigations. The absorbances of compound solutions were proportional to their concentrations between $2 \mathrm{x}$ $10^{-6}$ and $5 \times 10^{-5}$ moldm $^{-3}$ indicating that they would not aggregate by intermolecular stacking under the experimental conditions used.

\subsection{Spectrophotometric titrations of compounds with ds-polynucleotides}

UV-Vis absorption measurement is a simple but effective method for detecting complex formation. In general, when a small molecule interacts with DNA/RNA and form a new complex, changes in absorbance and the position of the absorption maxima should occur [38,39]. The interaction of compounds 13a-13f, 14a-14f, 15a-15f and 16a-16f towards $c t$ DNA and polyA-polyU were investigated by UV-Vis spectroscopy in a solution of phosphate buffer and DMSO (0.1\%). When aliquots of dissolved $c t$ DNA were added to the compound solutions, a hypochromic effect $(8-45 \%)$ was observed, indicating the disappearance of the free molecule and the formation of a new compoundDNA complex (Figure S1, Supplementary Information).

Spectrophotometric titration of compounds $13 \mathbf{a}-\mathbf{1 3 f}$ and $\mathbf{1 4 a}-\mathbf{1 4 f}$, which contain an aliphatic linker with both polynucleotides, resulted in a pronounced decrease of the absorption maxima at $\lambda>300 \mathrm{~nm}$ (Table 1, Figure S1, Supplementary Information). Except for 15c, which interacts with both polynucleotides, other compounds from the 15a-15f series containing a 1,4-bis(oxymethylene)phenyl linker were selective for ctDNA. The only exceptions were compounds from the $\mathbf{1 6 a}-\mathbf{1 6 f}$ series, which did not display shifts in the UV-Vis absorption maxima. In the UV-Vis spectra of compounds 14b, 14c, 13c, 13f and 15a-15c, decreases in absorption maxima were followed by bathochromic shifts $(\Delta \lambda=5-10 \mathrm{~nm})$ upon addition of $c t$ DNA. Further addition of the $c t$ DNA resulted in increased absorption maxima (Figure S1). These results suggested that the above mentioned compounds could form at least two different types of complex. Therefore, binding constants $\left(K_{\mathrm{s}}\right)$ were calculated at the $\mathrm{r} \geq 0.15(\mathrm{r}=$ 
[compound] $/[c t \mathrm{DNA}])$. At this ratio, changes in absorption maxima were too small for accurate calculation.

To assess the sequence selectivity of the compounds, the experiment was repeated with $d s$-RNA (polyA-polyU) (Figure S1). The addition of polyA-polyU to solutions of compounds containing an aliphatic linker, 13a-13f (with the exception of 13e) and 14a14f, induced a hypochromic (10-52\%) effect in their UV-Vis spectra. Furthermore, the hypochromic effect was accompanied by a small bathochromic $(2-8 \mathrm{~nm})$ shift in the UVVis spectra of the unsubstituted amidine and imidazoline derivatives 14a, 14c, 13a and 13c, as a result of complex formation. Titration of compounds with an aromatic linker, 15a-15f (with the exception of 15c) and 16a-16f, with polyA-polyU did not show any changes in UV-Vis spectra.

\section{Table 1}

Hypochromic effects $(\mathrm{H} / \%)^{\mathrm{a}}$, binding constants $\left(\log K_{s}\right)^{\mathrm{b}}$ and ratios $n^{\mathrm{c}}$ ([compound]/[polynucleotide phosphate]) calculated from the UV-VIS titrations of compounds with $d s$-DNA/RNA (at $\mathrm{pH} 7$, PBS, $I=0.015 \mathrm{M}$ ).

\begin{tabular}{|c|c|c|c|c|c|c|}
\hline \multirow{2}{*}{ Compd } & \multicolumn{3}{|c|}{ ctDNA } & \multicolumn{3}{|c|}{ polyA-polyU } \\
\hline & $\mathrm{H} / \%^{\mathrm{c}}$ & $\log K s$ & $n$ & $\mathrm{H} / \%^{\mathrm{c}}$ & $\log K s$ & $n$ \\
\hline $13 a$ & $13.3^{\mathrm{f}}$ & 6.61 & 0.05 & 45.9 & 5.70 & $0.3^{\mathrm{d}}$ \\
\hline $13 b$ & $24.0^{\mathrm{f}}$ & 6.33 & 0.09 & 32.3 & 5.69 & 0.58 \\
\hline $13 \mathrm{c}$ & $17.0^{\mathrm{f}}$ & 7.62 & 0.05 & 32.1 & 6.83 & 0.42 \\
\hline 13d & 45.8 & 6.56 & $0.15^{\mathrm{d}}$ & 26.6 & 7.12 & 0.84 \\
\hline $13 e$ & 27.2 & 7.04 & $0.05^{\mathrm{d}}$ & NB & NB & NB \\
\hline $13 \mathrm{f}$ & 44.6 & 6.55 & 0.19 & 9.9 & 6.54 & $0.13^{\mathrm{d}}$ \\
\hline $14 a$ & 36.6 & 5.93 & 0.47 & 24.4 & 6.65 & $0.43^{\mathrm{d}}$ \\
\hline $14 b$ & $20.5^{\mathrm{f}}$ & 5.68 & 0.67 & 12.9 & 6.16 & $0.30^{\mathrm{d}}$ \\
\hline $14 \mathrm{c}$ & 28.1 & 6.23 & 0.89 & 3.4 & 7.17 & $0.85^{\mathrm{d}}$ \\
\hline 14d & 35.4 & 5.93 & 0.47 & 51.2 & 6.43 & 0.35 \\
\hline $14 \mathrm{e}$ & 35.3 & 5.21 & 0.21 & 52.2 & 5.12 & 0.19 \\
\hline $14 f$ & 35.8 & 6.22 & 0.29 & 41.1 & 5.76 & 0.31 \\
\hline $15 \mathbf{a}$ & 8.7 & 6.80 & $0.3^{\mathrm{d}}$ & $11.3^{\mathrm{e}}$ & - & - \\
\hline $15 b$ & $23.2^{\mathrm{f}}$ & 7.31 & $0.9^{\mathrm{d}}$ & $41.5^{\mathrm{e}}$ & - & - \\
\hline $15 c$ & $5.9^{\mathrm{f}}$ & 6.05 & 0.18 & 10.7 & - & - \\
\hline $15 d$ & 24.5 & 5.92 & 0.17 & NB & - & - \\
\hline $15 e$ & 26.7 & 6.33 & 0.65 & NB & - & - \\
\hline $15 f$ & 35.2 & 6.18 & 0.10 & $6.0^{\mathrm{e}}$ & - & - \\
\hline
\end{tabular}

${ }^{[a]}$ Hypochromic effect calculated by Scatchard for compounds;

$\mathrm{H}=(\mathrm{Abs}$ (compound) $-\mathrm{Abs}($ complex $)) / \mathrm{Abs}$ (compound) $\mathrm{x} 100$

${ }^{[b]}$ Titration data were processed according to the Scatchard equation

[c] Accuracy of $n \pm 10-30 \%$, consequently $\log K_{s}$ values vary in the same order of magnitude.

${ }^{[\mathrm{d}]} \mathrm{n}=$ fix 
${ }^{[\mathrm{e}]}$ Hypochromic effect calculated from experimental data: (Abs(compound) -Abs(complex)) / Abs(compound) x 100

$-=$ changes were too small for accurate calculation of binding constants

${ }^{[\mathrm{f}]}$ mixed binding mode, binding constant were calculated in range $\mathrm{r} \geq 0.1$

$\mathrm{NB}=$ no bindng

Overall, the results of spectrophotometric titration of the $13 \mathbf{a}-\mathbf{1 3 f}, \mathbf{1 4 a}-14 \mathrm{f}$ and $\mathbf{1 5 a}-$ $15 f$ series of compounds showed that they had higher affinity for $c t$ DNA than for polyApolyU. Since compounds $\mathbf{1 6 a}-\mathbf{1 6 f}$ did not show affinity for either polynucleotide, it can be concluded that the 4,4'-bis(oxymethylene)biphenyl linker had a detrimental effect on the interaction. Therefore, these compounds were not evaluated in further DNA/RNA binding assays.

\subsection{Thermal denaturation experiments}

The evaluation of the DNA/RNA melting temperature $\left(T_{m}\right)$ as a result of ligand intercalation or minor grove binding can be used as an indicator of the interaction between compounds and polynucleotides [40-42]. Temperature-dependent DNA denaturation is associated with changes to the absorbance spectrum of the biomolecule as the result of the breakage of hydrogen bonds between base pairs. Accordingly, to assess the binding affinity of synthesized compounds towards DNA/RNA, the Tm values of ctDNA and polyA-polyU, in the absence and presence of the symmetrical bisbenzimidazoles, were measured (Table 2).

\section{Table 2}

$\Delta T_{\mathrm{m}}$ values of compounds with ctDNA and polyA-polyU upon addition of compounds at different ratio $r^{\mathrm{a}}(\mathrm{PBS}, \mathrm{pH}=7)$. $^{\mathrm{b}}$

\begin{tabular}{ccccccc}
\hline & \multicolumn{3}{c}{ ctDNA } & \multicolumn{3}{c}{ polyA-polyU } \\
Compd & $\mathbf{0 . 1}$ & $\mathbf{0 . 3}$ & $\mathbf{0 . 5}$ & $\mathbf{0 . 1}$ & $\mathbf{0 . 3}$ & $\mathbf{0 . 5}$ \\
\hline 13a & 13.56 & 12.96 & 13.84 & 1.51 & 0.61 & 9.27 \\
& & & & $33.49^{\mathrm{c}}$ & $37.3^{\mathrm{c}}$ & $27.6^{\mathrm{c}}$ \\
$\mathbf{1 3 b}$ & 13.77 & 14.48 & 14.77 & 0.90 & 0.53 & 0.82 \\
& & & & $49.71^{\mathrm{c}}$ & $49.71^{\mathrm{c}}$ & $44.01^{\mathrm{c}}$ \\
$\mathbf{1 3 c}$ & 13.48 & 13.79 & 19.12 & 1.58 & 1.75 & 2.70 \\
& & & & & $18.95^{\mathrm{c}}$ & $17.05^{\mathrm{c}}$ \\
$\mathbf{1 3 d}$ & 0.81 & 1.28 & 1.97 & 0.80 & 1.27 & 2.03
\end{tabular}




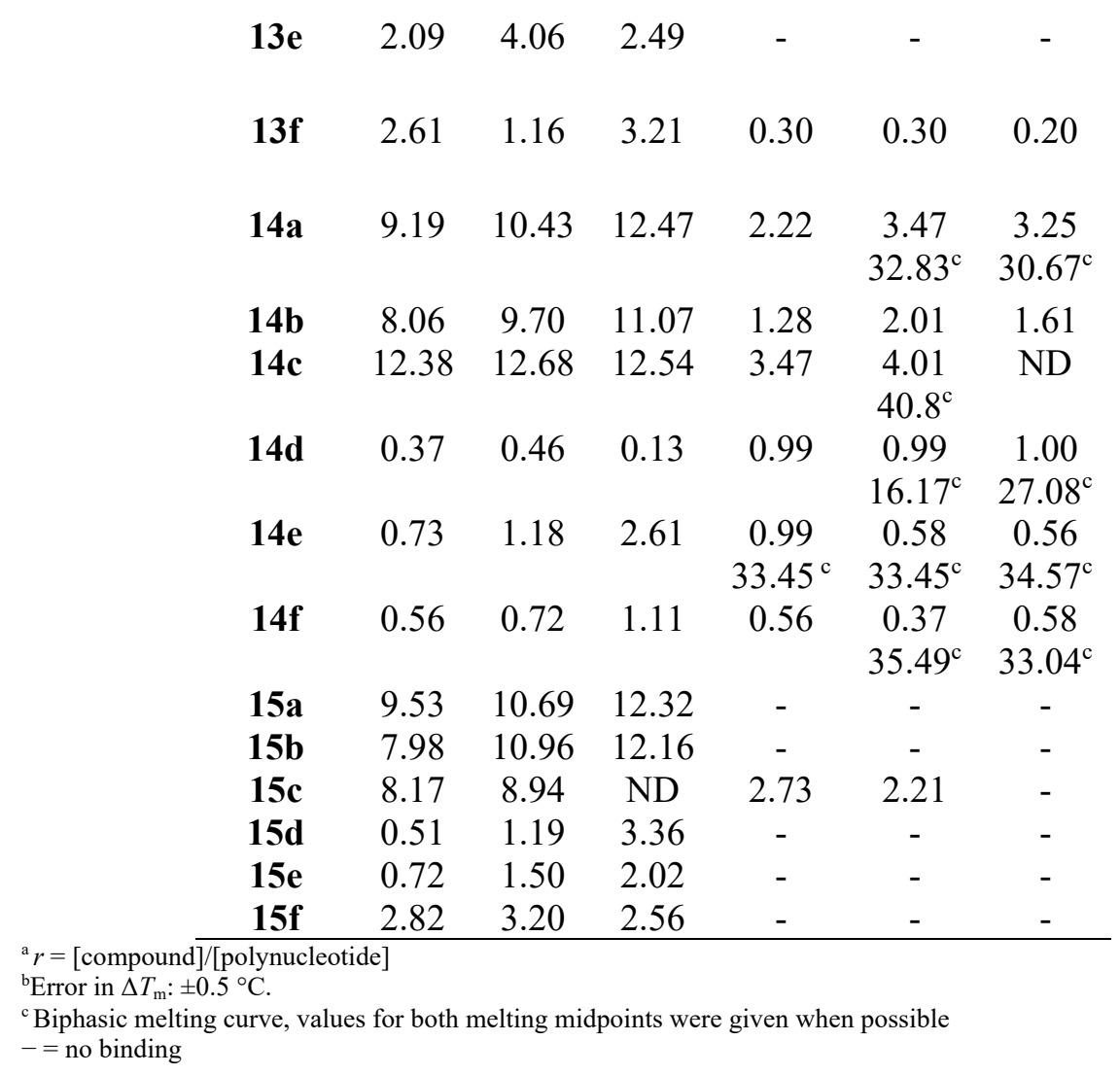

Generally, the denaturation experiments indicated a higher affinity of the compounds to $c t$ DNA than to the polyA-polyU polynucleotide. This was also confirmed with spectrophotometric titrations. Furthermore, amidine derivatives 13a-13c, 14a-14c and 15a-15c showed higher stabilization of $c t$ DNA compared to non-amidines $13 \mathbf{d}-\mathbf{1 3 f}$, 14d-14f and 15d-15f, confirming the impact of the amidine moiety on DNA/RNA interactions. Thus, a significant binding affinity was found for $13 \mathbf{a}-\mathbf{1 3 c}, \mathbf{1 4 a}-\mathbf{1 4 c}$ and 15a-15c, which showed the highest $\Delta T_{m}$ values $\left(>9{ }^{\circ} \mathrm{C}\right)$ for $c \operatorname{tDNA}(\mathrm{r}=0.3)$. Conversely, all compounds showed slight enhancement in thermal stabilities for polyApolyU. Moreover, while melting transitions in ctDNA experiments were typically monophasic, in the polyA-polyU experiments, strong biphasic transitions occurred, with the exception of $\mathbf{1 4 b}, \mathbf{1 3 f}, \mathbf{1 3 d}$ and $\mathbf{1 5 c}$ (Table 2). This indicates a secondary binding mode, i.e. agglomeration of these compounds along the polynucleotide. 


\subsection{Circular Dichroism (CD) experiments}

Circular dichroism (CD) experiments can be used to determine binding and conformational changes of polynucleotides. The peak observed at $275 \mathrm{~nm}$ relates to $\pi-\pi$ stacking of the DNA bases, and the peak at $245 \mathrm{~nm}$ indicates the helicity, which is characteristic of DNA in right-handed B form. The binding mode of achiral small molecules within the chiral DNA/RNA helix can result in an induced CD spectrum (ICD). Compounds that bind into the minor groove of DNA can induce a new peak in the spectrum, arising from the coupling of electronic transition moments of the ligand and DNA bases in an achiral environment $[43,44]$.

The results of $\mathrm{CD}$ studies indicated clear changes in the $\mathrm{CD}$ spectra for amidine derivatives 13a-13c, 14a-14c and 15a-15c (Figure S2, Supplementary Information); the negative band showed slight hyperchromicity, while the positive band exhibited significant hypochromicity and a bathochromic shift associated with the partial disruption of the polynucleotide helical chirality caused by the binding of a small molecule. Importantly, a strong induced CD signal (ICD) in the range of 300-500 nm appeared. Furthermore, the positive ICD band suggests that the compounds are positioned along the minor groove, identifying this as the dominant binding mode.

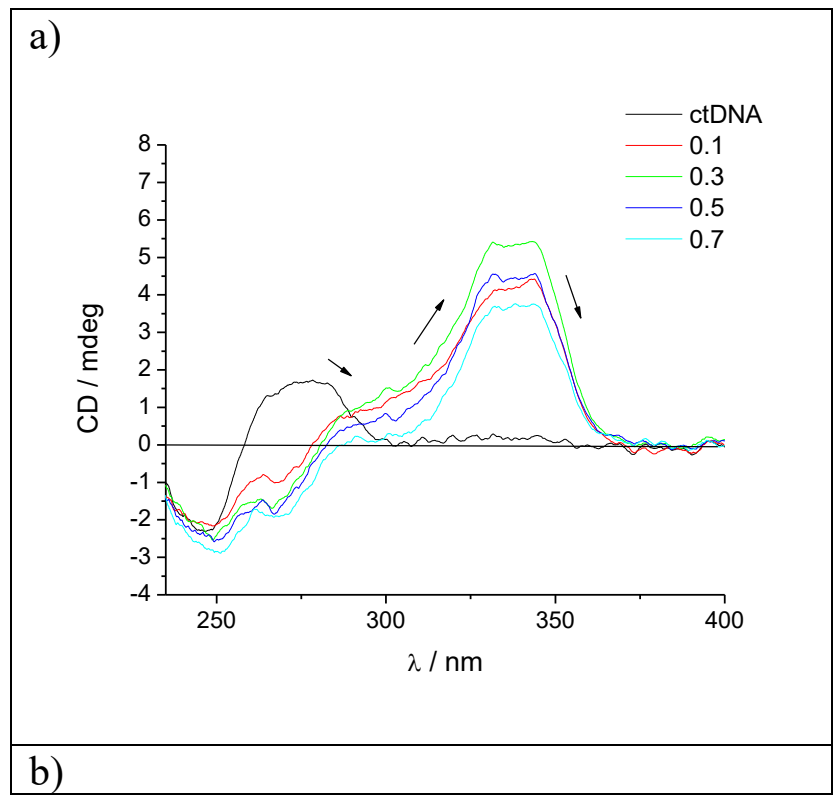




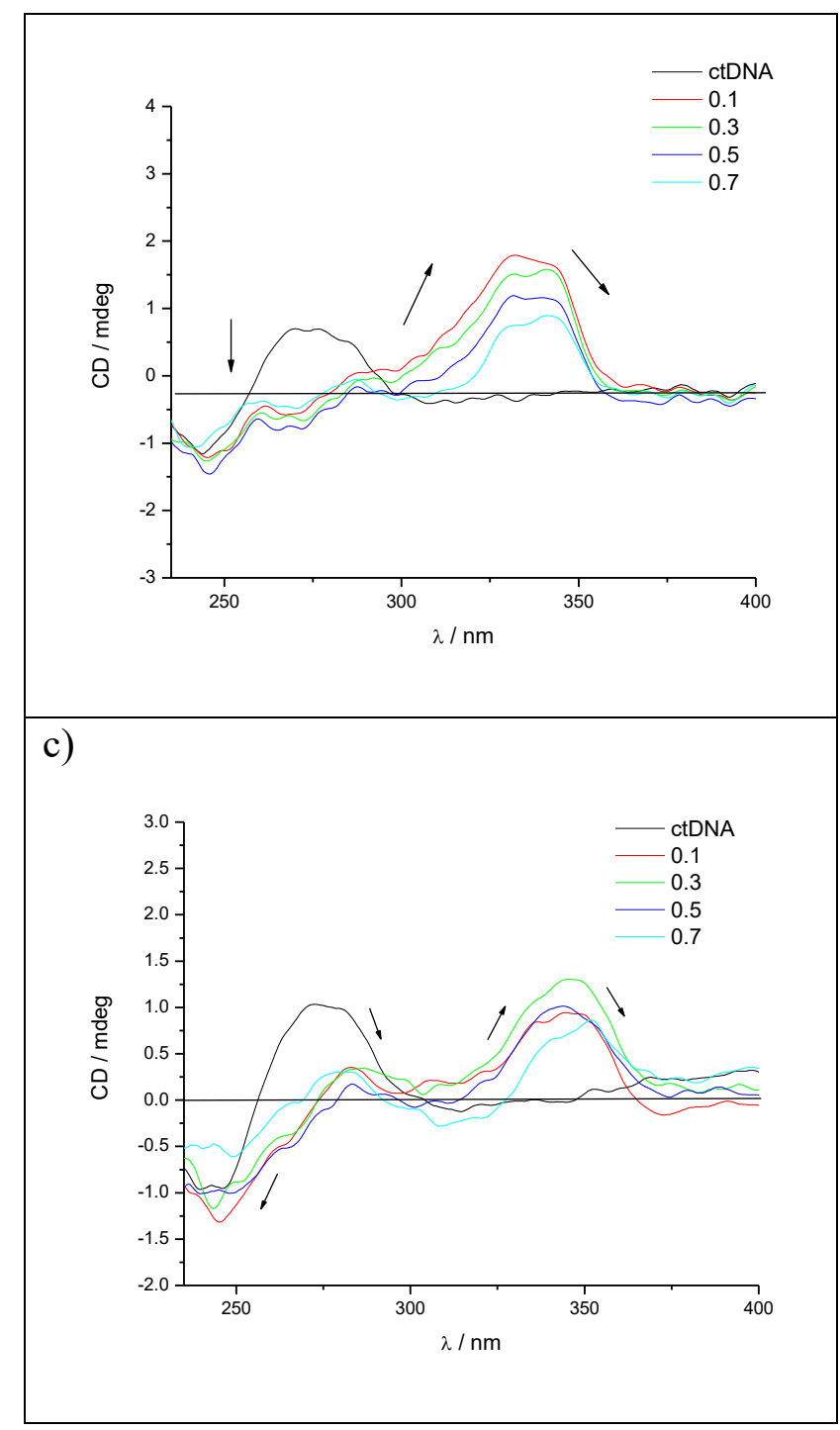

Fig. 2. Induced CD spectra of dimeric compound 15a (a), compound 15b (b) and compound 15c (c) with $c t$ DNA $(r=0-0.7)$.

Conversely, when non-amidine derivatives 13d-13f, 14d-14f and $\mathbf{1 5 d}-\mathbf{1 5 f}$ were combined with $c t$ DNA, there was little or no perturbation of base stacking, with the helicity bands retaining their basic shape (Figure S2, Supplementary Information).

These findings are in agreement with UV-Vis titrations and denaturation experiments, which also indicated the lower affinity of these compounds compared to amidine derivatives. Most likely, the lack of the amidine groups, which are able to form additional H-bonds with bases, decreases the possibility that stable complexes could 
form. The strongly non-linear dependence of the ICD intensity at $>300 \mathrm{~nm}$ is in agreement with the calculated values of the UV-Vis titrations and ratios obtained in denaturation experiments. The binding mode of the novel compounds was further investigated by measuring their induced $\mathrm{CD}$ in the presence of polyA-polyU. In contrast to $c t \mathrm{DNA}$, the addition of polyA-polyU to unsubstituted amidine derivatives (Figure $\mathrm{S} 2$, Supplementary Information) resulted in hypochromicity and a bathochromic shift of the CD band at $263 \mathrm{~nm}$. Positive ICD bands appeared at $300 \mathrm{~nm}$, indicating groove binding as the dominant binding mode. Isopropylamidine derivatives showed low affinity for polyA-polyU. Interestingly, the ICD spectra of imidazoline derivatives $13 \mathbf{c}, 14 \mathbf{c}$ and $15 \mathbf{c}$ showed a negative signal at $>300 \mathrm{~nm}$, which may indicate intercalation as a possible binding mode. Moreover, minimal changes in CD spectra upon addition of non-amidine compounds to polyA-polyU were observed. This is in agreement with the results on UVVis titration and denaturation experiments.

\subsection{Screening of the antitrypanosomal activity and structure-activity relationship (SAR)}

Results of the in vitro testing of novel bis-[benzimidazol-2-yl-fur-5-yl-(1,2,3)triazolyl] derivatives 13a-13f, 14a-14f, 15a-15f and 16a-16f and nifurtimox, as a reference drug, against bloodstream form $T$. brucei are summarized in Table 3. The cytotoxicity of the most active compounds $\left(\mathrm{IC}_{50}<5 \mu \mathrm{M}\right)$ was also assessed using the rat myoblast cell line L6.

\section{Table 3}

Antitrypanosomal activity ${ }^{\mathrm{a}}$ of compounds 13a-13f, 14a-14f, 15a-15f and 16a-16f against Trypanosoma brucei strain.

\begin{tabular}{|c|c|c|c|c|c|c|}
\hline \multirow{2}{*}{ Compd } & \multirow{2}{*}{$\mathbf{R}$} & \multirow{2}{*}{$\mathbf{X}$} & \multicolumn{2}{|c|}{ T. brucei } & \multirow{2}{*}{$\begin{array}{l}\text { L6 cells } \\
\text { IC }_{50} / \mu M\end{array}$} & \multirow[t]{2}{*}{$\mathbf{S I}^{\mathbf{c}}$} \\
\hline & & & $\mathrm{IC}_{50} / \boldsymbol{\mu M}$ & $\mathrm{IC}_{90} / \boldsymbol{\mu} \mathrm{M}$ & & \\
\hline $13 a$ & & $\mathrm{CH}_{2}$ & $3.6 \pm 0.4$ & $5.5 \pm 0.2$ & $198 \pm 3$ & 55 \\
\hline $13 b$ & 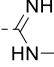 & $\mathrm{CH}_{2}$ & $5.1 \pm 0.2$ & $8.2 \pm 1.0$ & $104 \pm 3$ & 20 \\
\hline
\end{tabular}




\begin{tabular}{|c|c|c|c|c|c|c|}
\hline $13 c$ & & $\mathrm{CH}_{2}$ & $3.9 \pm 0.3$ & $5.4 \pm 0.1$ & $216 \pm 21$ & 55 \\
\hline 13d & $\mathrm{F}$ & $\mathrm{CH}_{2}$ & $4.0 \pm 0.2$ & $8.9 \pm 0.6$ & $221 \pm 12$ & 55 \\
\hline $13 \mathrm{e}$ & $\mathrm{Cl}$ & $\mathrm{CH}_{2}$ & $3.0 \pm 0.3$ & $7.2 \pm 0.7$ & $>300$ & $>100$ \\
\hline $13 f$ & $\mathrm{H}$ & $\mathrm{CH}_{2}$ & $>15$ & - & - & - \\
\hline $14 a$ & & $\mathrm{O}$ & $3.3 \pm 0.3$ & $4.7 \pm 0.1$ & $88.6 \pm 2.1$ & 25 \\
\hline $14 b$ & & $\mathrm{O}$ & $7.9 \pm 0.1$ & $10.8 \pm 0.1$ & - & - \\
\hline $14 c$ & & $\mathrm{O}$ & $3.8 \pm 1.0$ & $6.0 \pm 0.4$ & $122 \pm 3$ & 30 \\
\hline 14d & $\mathrm{F}$ & $\mathrm{O}$ & $7.9 \pm 0.3$ & $>25$ & - & - \\
\hline $14 \mathrm{e}$ & $\mathrm{Cl}$ & $\mathrm{O}$ & $6.4 \pm 0.6$ & $11.8 \pm 1.1$ & - & - \\
\hline $14 f$ & $\mathrm{H}$ & $\mathrm{O}$ & $>15$ & - & - & - \\
\hline $15 a$ & & & $1.3 \pm 0.1$ & $5.6 \pm 0.4$ & $39.6 \pm 2.0$ & 30 \\
\hline $15 b$ & & & $1.5 \pm 0.1$ & $2.8 \pm 0.4$ & $121 \pm 5$ & 80 \\
\hline $15 \mathrm{c}$ & & & $0.75 \pm 0.15$ & $1.5 \pm 0.1$ & $60.7 \pm 3.1$ & 80 \\
\hline $15 d$ & $\mathrm{~F}$ & & $3.4 \pm 0.2$ & $6.7 \pm 1.0$ & $219 \pm 41$ & 65 \\
\hline $15 \mathrm{e}$ & $\mathrm{Cl}$ & & $1.4 \pm 0.2$ & $2.5 \pm 0.4$ & $>270$ & $>190$ \\
\hline $15 f$ & $\mathrm{H}$ & & $>15$ & - & - & - \\
\hline $16 a$ & & & $>10$ & - & - & - \\
\hline $16 b$ & & & $>10$ & - & - & - \\
\hline $16 \mathrm{c}$ & & & $>10$ & - & - & - \\
\hline 16d & $\mathrm{F}$ & & $>15$ & - & - & - \\
\hline $16 e$ & $\mathrm{Cl}$ & & $0.37 \pm 0.06$ & $9.7 \pm 0.03$ & $30.4 \pm 6.1$ & 80 \\
\hline $16 f$ & $\mathrm{H}$ & & $>10$ & - & - & - \\
\hline ifurtimox & - & & $4.4 \pm 0.7^{b}$ & - & & \\
\hline
\end{tabular}

${ }^{a}$ In vitro activity against bloodstream form of $T$. brucei expressed as the concentration that inhibited growth by $50 \%\left(\mathrm{IC}_{50}\right)$ and $90 \%$ $\left(\mathrm{IC}_{90}\right)$. Data are the mean of triplicate experiments $\pm \mathrm{SEM}$.

${ }^{\mathrm{b}}$ Taken from ref. [45].

c Selectivity index: $\mathrm{IC}_{50} \mathrm{~Tb} / \mathrm{L} 6$ cells.

The effects of both substituents at the 5-position on the benzimidazole moiety and varied aliphatic and aromatic central linkers were investigated (Figure 3). With the exception of the 5-unsubstituted benzimidazoles 13f, $14 f$ and $15 f$ and the bisbenzimidazoles 16a-16d and 16f, which have a 1,4-bis(oxymethylene)phenyl linker, all 
compounds showed good activity against $T$. brucei, with $\mathrm{IC}_{50}$ values ranging from 0.75 $\mu \mathrm{M}$ to $7.9 \mu \mathrm{M}$. Among the 5-amidinobenzimidazoles, non-substituted amidines and imidazolines exhibited better potencies than their $N$-isopropyl-substituted counterparts. Similarly, non-substituted amidine 13a, 15a and imidazoline 13c, 15c benzimidazoles were generally the most active compounds, and were also more potent than nifurtimox. From non-amidine substituted benzimidazoles, antitrypanosomal activities decreased in the following order: $\mathrm{Cl}>\mathrm{F}>\mathrm{H}$. 5-unsubstituted benzimidazoles 13f-16f had no significant potency against $T$. brucei $\left(\mathrm{IC}_{50}>10 \mu \mathrm{M}\right)$, revealing that 5 -substitutions in the benzimidazole are crucial for activity. Assessment of the effect of central linkers in the symmetric bis-benzimidazoles on antitrypanosomal potencies, showed that compounds bearing propylene (13a-13f) and oxydimethylene (14a-14f) linkers exhibited comparable activities, indicating that the aliphatic spacer was not a determinant of the activity. However, the placement of aromatic linkers did significantly affected potency against $T$. brucei. For example, compounds with 1,4-bis(oxymethylene)phenyl were devoid of activity. The only exception was 5-chlorobenzimidazole 16c, which exerted a strong inhibitory effect $\left(\mathrm{IC}_{50}=0.37 \mu \mathrm{M}\right)$, although its $\mathrm{IC}_{90}$ value of $9.7 \mu \mathrm{M}$ was relatively high compared to the majority of the 5-substituted bis-benzimidazoles. In contrast, the 4,4'bis(oxymethylene)biphenyl linker increased the trypanocidal activity $\left(\mathrm{IC}_{50}=0.75-3.4\right.$ $\mu \mathrm{M})$ of 5 -substituted benzimidazoles 15a-15e. Compound 15c, which contains both the imidazoline fragment and the 1,4-dimethoxyphenyl spacer had potent activity $\left(\mathrm{IC}_{50}=\right.$ $\left.0.75 \mu \mathrm{M}, \mathrm{IC}_{90}=1.5 \mu \mathrm{M}\right)$. The compounds displayed only moderate or negligible cytotoxicity when tested against L6 cells, with selectivity indices ranging from 20 (13b) to beyond $270(\mathbf{1 5 e})$. 


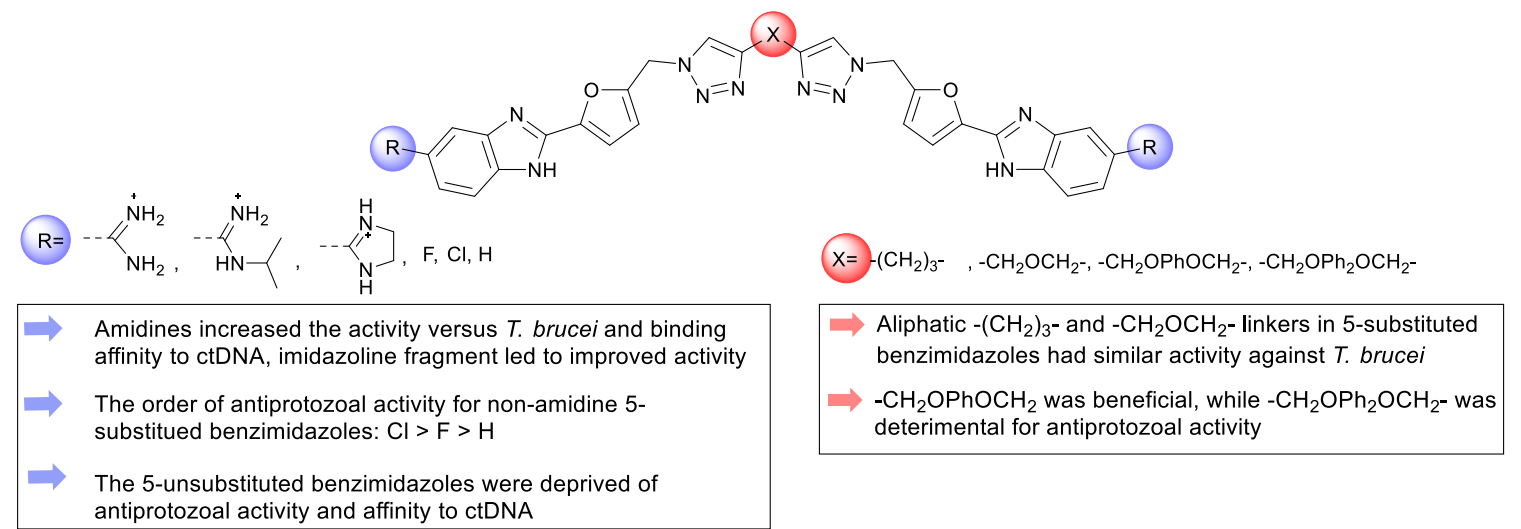

Fig. 3. Structure-activity relationship (SAR) of novel bis-benzimidazoles series with diverse aliphatic and aromatic linkers.

We found a correlation between binding affinities to $c t$ DNA and antitrypanosomal activity in the novel bis-benzimidazoles. For example, compounds from the 16a-16f series that were inactive also showed no affinity to the polynucleotides. Similarly, unsubstituted benzimidazoles $\mathbf{1 3 f}-\mathbf{1 6 f}$, which had the lowest affinity for $c t$ DNA relative to corresponding analogs, displayed no significant antitrypanosomal potency. In contrast, amidines and imidazolines, which showed the highest and most selective binding affinity to $c t \mathrm{DNA}$, also displayed the best activity against $T$. brucei. Structural requirements that were found to influence antitrypanosomal activity and binding affinity to ctDNA are presented in Figure 3.

\subsection{Molecular modelling of bis-benzimidazole derivative $\mathbf{1 5 c}$}

To additionally verify suggested interactions of $\mathbf{1 5 c}$, the compound that exhibited the most potent antitrypanocidal activity, binding into the DNA minor groove was further analysed using in silico molecular studies. Two B-DNA oligomers with different base pair sequences, the $12 \mathrm{bp}$ DNA d[(CGCGAATTCGCG)]2 (pdb: 1BNA) and 14 bp DNA $\mathrm{d}\left[(\text { CTACCGATAAGCAG) }]_{2}\right.$ (pdb: 5XOG), were used as DNA templates. It was found that compound 15c fits nicely into the minor groove of both B-DNA models (Figure 4a and $4 \mathrm{~b}$ ). The complex was stabilized with hydrogen bonds and electrostatic interactions with different nucleotide units, phosphate groups, sugars and bases. In the $14 \mathrm{bp}$ DNA15c complex the ligand has interacted with DNA through hydrogen-bonds with phosphate group at A10 and with T8 O2 in one run, and with $\mathrm{H}$-bonds T26 O2, T8 O2 
and with phosphate group at C23 in the other run. During MD simulations of the $12 \mathrm{bp}$ DNA-15c complex the ligand established hydrogen bonds with phosphate groups at T7, A17 and terminal G12. It should be noted that the shape of the 12-mer DNA after binding of 15c was preserved during the simulation in accordance with previous results $[46,47]$ (Figure 4c).

Molecular modelling studies revealed that compound 15c could tightly bind within the $c t$ DNA minor groove, whereas $\mathbf{1 5 c}$ could not bind as efficiently to the much narrower polyA-polyU, as is evident from the thermal denaturation and $\mathrm{CD}$ spectroscopy results (Table 2, Figure 2c).

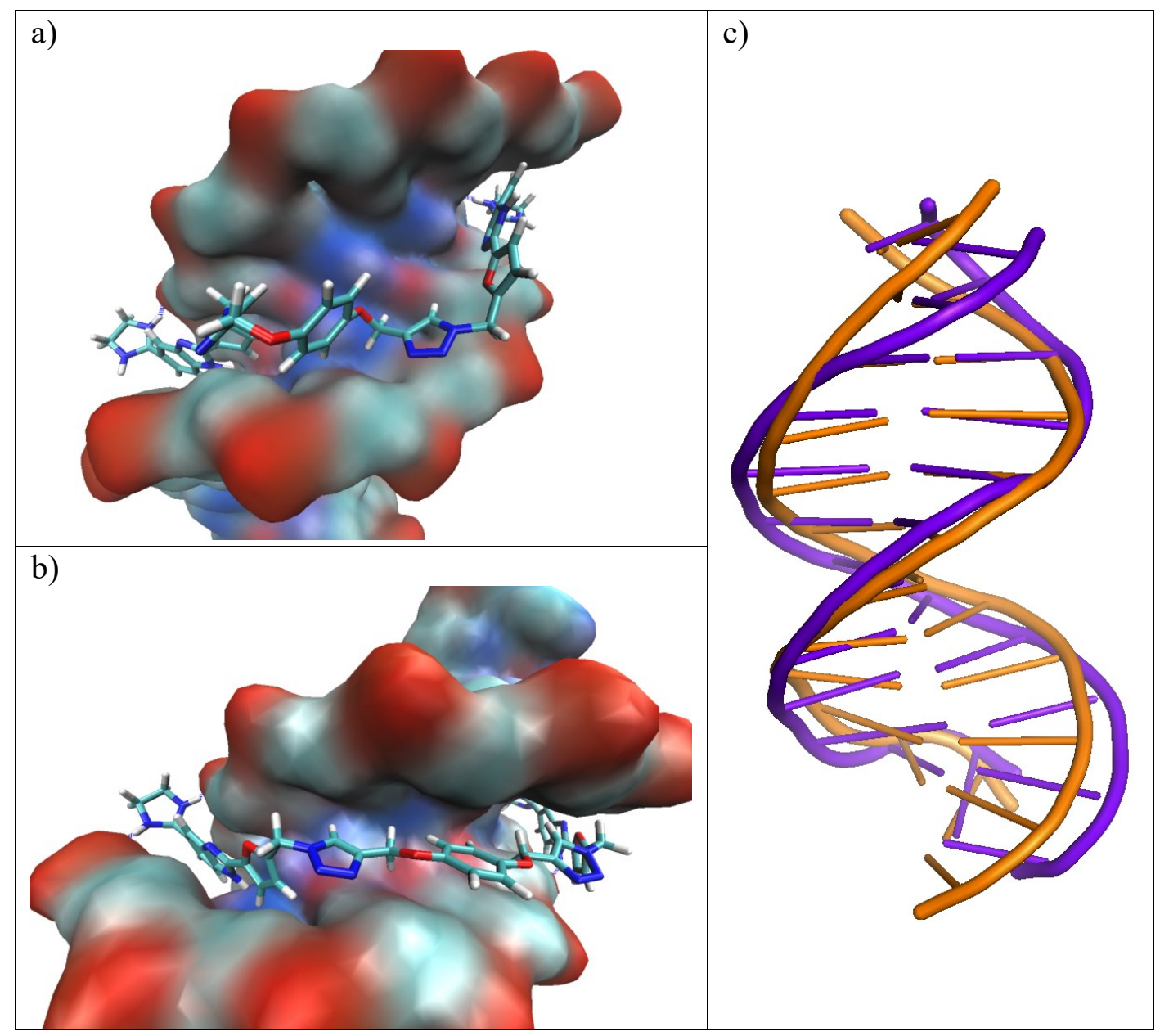

Fig. 4. Complex of 15c with 14 bp DNA d[(CTACCGATAAGCAG) $]_{2}$ (a). The ligand is shown in stick representation and the oligonucleotide is represented by its electrostatic potential surface with phosphate group at A10 and with T8 O2 that interact with 15c through hydrogen bonds (blue dotted line). Compound 15c bound into the minor groove 


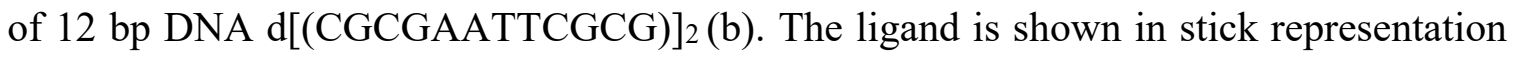
and the oligonucleotide is represented by its electrostatic potential surface with phosphate group at T7, A17 and G12 interacting with 15c through hydrogen bonds (blue dotted line). Aligment of the $12 \mathrm{bp}$ DNA structures before (orange) and after (violet) binding the compound 15c (c).

\section{Conclusions}

We report here an efficient pathway for the construction of the dimeric benzimidazole-furan-1,2,3-triazole series 13a-13f, 14a-14f, 15a-15f and 16a-16f. These contain symmetric units connected via varied aliphatic and aromatic central linkers. DNA/RNA binding assays showed that bis-5-amidinobenzimidazoles 13a-13c, 14a-14c and 15a-15c had the highest affinity and selectivity for $c t$ DNA. The strong interactions with $c t$ DNA were supported by spectrophotometric titrations that exhibited a steady decrease in absorbance, accompanied with blue shift. Furthermore, thermal denaturation experiments, which identified $\Delta T_{m}$ values for $c t$ DNA above $9{ }^{\circ} \mathrm{C}$, and changes in the CD spectra for bis-5-amidinobenzimidazoles were consistent with non-intercalative and minor-groove binding, as dominant binding mode. Results of antitrypanosomal evaluations showed that bis-5-amidinobenzimidazoles 15a-15c, with a 1,4bis(oxymethylene)phenyl spacer, exerted the highest activity against T. brucei.

Overall, the results revealed that amidino fragments at the 5-position of the benzimidazole ring play a key role in binding affinity to $c t \mathrm{DNA}$, while the 5-substituent and linker are crucial determinants of antiprotozoal activity. We found that imidazoline and 1,4-bis(oxymethylene)phenyl were favourable for strong antiprotozoal activity. Bisbenzimidazole imidazoline 15c, which contains a 1,4-bis(oxymethylene)phenyl, was the most potent derivative with 6-fold higher activity than nifurtimox. Taken together, our results suggest that compound 15c binds to ctDNA via a groove binding mode and that this DNA interacting property may be responsible for its antitrypanosomal potency. Moreover, molecular modelling revealed that compound $\mathbf{1 5 c}$ adopts a concave shape that fits into the minor groove of DNA. The demonstration of DNA binding affinity and 
antitrypanosomal potency of this type of compounds, together with their low toxicity against mammalian cells, also suggests that bis-amidinobenzimidazole-furan-azole analogs provide an interesting framework for future structural optimization to obtain promising agents for treatment of human African trypanosomiasis (HAT).

\section{Experimental}

\subsection{General}

All solvents were purified using recommended drying agents and/or distilled over 3 $\AA$ molecular sieves. For monitoring the progress of a reaction and for comparison purposes, thin layer chromatography (TLC) was performed on pre-coated Merck silica gel 60F-254 plates using an appropriate solvent system and the spots were detected under UV light (254 nm). For column chromatography, silica gel (Fluka, 0.063-0.2 mm) was employed, and glass columns slurry-packed under gravity. Melting points (uncorrected) were determined with Kofler micro hot-stage (Reichert, Wien). ${ }^{1} \mathrm{H}$ and ${ }^{13} \mathrm{C}$ NMR spectra were acquired on a Bruker 300 and $600 \mathrm{MHz}$ NMR spectrometer, or $300 \mathrm{MHz}$ Agilent Technologies DD2 NMR spectrometer. All data were recorded in DMSO- $d_{6}$ at $298 \mathrm{~K}$. Chemical shifts were referenced to the residual solvent signal of DMSO at $\delta 2.50 \mathrm{ppm}$ for ${ }^{1} \mathrm{H}$ and $\delta 39.50 \mathrm{ppm}$ for ${ }^{13} \mathrm{C}$. Individual resonances were assigned on the basis of their chemical shifts, signal intensities, multiplicity of resonances and $\mathrm{H}-\mathrm{H}$ coupling constants. High performance liquid chromatography was performed on an Agilent 1100 series system with UV detection (photodiode array detector) using Zorbax C18 reversephase analytical column $(2.1$ x $30 \mathrm{~mm}, 3.5 \mu \mathrm{m})$. All compounds used for biological evaluation showed $>95 \%$ purity in this HPLC system. Microwave-assisted syntheses were performed in a Milestone start S microwave oven using glass cuvettes at $80^{\circ} \mathrm{C}$ and $800 \mathrm{~W}$ under pressure of 1 bar.

\subsection{Experimental procedures for the preparation of compounds}

Compound 5-(chloromethyl)furan-2-carbaldehyde (2) [36], 1,4-bis(prop-2-yn-1-

yloxy)benzene (6) [48], 4,4'-bis(prop-2-yn-1-yloxy)-1,1'-biphenyl (7) [49], 3,4diaminobenzimidamide (12a) [37], 3,4-diamino- $N$-isopropylbenzimidamide (12b) [37], 
4-(4,5-dihydro-1H-imidazol-2-yl)benzene-1,2-diamine (12c) [37] were prepared according to known procedures.

4.2.1. 5-(Azidomethyl)furan-2-carbaldehyde (3). Compound 2 (634 $\mathrm{mg}, 4.39 \mathrm{mmol})$ and $\mathrm{NaN}_{3}(1.14 \mathrm{~g}, 17.54 \mathrm{mmol})$ were stirred in acetonitrile $(20 \mathrm{~mL})$ under reflux over night. The solvent was evaporated to dryness and the residue was purified by column chromatography $\left(\mathrm{CH}_{2} \mathrm{Cl}_{2}\right.$ as eluent) to obtain 3 as yellow oil $(640.1 \mathrm{mg}, 97 \%) .{ }^{1} \mathrm{H}$ NMR (300 MHz, DMSO) $\delta 9.59(1 \mathrm{H}, \mathrm{s}, \mathrm{CHO}), 7.53(1 \mathrm{H}, \mathrm{d}, J=3.5 \mathrm{~Hz}, \mathrm{H} 3$ '), $6.78(1 \mathrm{H}, \mathrm{d}, J=$ $3.5 \mathrm{~Hz}, \mathrm{H} 4$ '), $4.63\left(2 \mathrm{H}, \mathrm{s}, \mathrm{CH}_{2}\right) .{ }^{13} \mathrm{C}$ NMR (75 MHz, DMSO) $\delta 178.50,156.04,152.50$, $123.89,112.68,36.82$.

\subsubsection{General procedure for the synthesis of compounds $\mathbf{8}-11$}

The corresponding terminal alkyne (4-7) was dissolved in $0.5 \mathrm{~mL}$ DMF and $t-\mathrm{BuOH}$ : $\mathrm{H}_{2} \mathrm{O}=1: 1(2-3 \mathrm{~mL}) . \mathrm{Cu}(0)(0.5 \mathrm{eq}), 1 \mathrm{M} \mathrm{CuSO} 4$ (1 eq) and azido-derivative 3 (2.2 eq) were added to the reaction mixture and stirred under microwave irradiation for $1.5 \mathrm{~h}$ at 80 ${ }^{\circ} \mathrm{C}$ and $300 \mathrm{~W}$. The solvent was evaporated and the residue was purified by column chromatography using $\mathrm{CH}_{2} \mathrm{Cl}_{2}$ : $\mathrm{CH}_{3} \mathrm{OH}=100: 1$ as an initial eluent.

\subsubsection{1,3-Bis\{[1-(5-formylfuran-2-yl)methylene]-1H-1,2,3-triazole-4-yl\}propane}

(8). Compound 8 was prepared using the above mentioned procedure from 1,6-heptadiin 4 $(0.25 \mathrm{~mL}, 2.17 \mathrm{mmol})$ to obtain 8 as white powder $\left(407.6 \mathrm{mg}, 48 \%\right.$, m.p. $\left.=142-144{ }^{\circ} \mathrm{C}\right)$. ${ }^{1} \mathrm{H}$ NMR (300 MHz, DMSO) $\delta 9.56$ (2H, s, CHO), 7.95 (2H, s, H5"), 7.52 (2H, d, $J=3.5$ $\left.\mathrm{Hz}, \mathrm{H} 3^{\prime}\right), 6.76\left(2 \mathrm{H}, \mathrm{d}, J=3.5 \mathrm{~Hz}, \mathrm{H} 4{ }^{\prime}\right), 5.74\left(2 \mathrm{H}, \mathrm{s}, \mathrm{CH}_{2}\right), 2.66(4 \mathrm{H}, \mathrm{t}, J=7.5 \mathrm{~Hz}$, $\left.\underline{\mathrm{CH}}_{2} \mathrm{CH}_{2} \underline{\mathrm{CH}}_{2}\right), 1.89\left(2 \mathrm{H}, \mathrm{dd}, J=15.0,7.4 \mathrm{~Hz}, \mathrm{CH}_{2} \underline{\mathrm{CH}}_{2} \mathrm{CH}_{2} .{ }^{13} \mathrm{C} \mathrm{NMR}(75 \mathrm{MHz}\right.$, DMSO) $\delta 178.39,154.90,152.37,146.87,124.04,122.39,112.23,45.67,28.62,24.42$.

\subsubsection{Bis\{[1-(5-formylfuran-2-yl)methyl])-1H-1,2,3-triazole-4-yl\}dimethylene ether}

(9). Compound 9 was prepared using the above mentioned procedure from propargyl ether $5(0.21 \mathrm{~mL}, 2.05 \mathrm{mmol})$ to obtain 9 as yellow powder $(178.1 \mathrm{mg}, 23 \%$, m.p. $=102-$ $\left.105^{\circ} \mathrm{C}\right) .{ }^{1} \mathrm{H}$ NMR $(600 \mathrm{MHz}, \mathrm{DMSO}) \delta 9.56(2 \mathrm{H}, \mathrm{s}, \mathrm{CHO}), 8.19(2 \mathrm{H}, \mathrm{s}, \mathrm{H} 5 "), 7.52(2 \mathrm{H}$, $\left.\mathrm{d}, J=3.5 \mathrm{~Hz}, \mathrm{H} 3^{\prime}\right), 6.78\left(2 \mathrm{H}, \mathrm{d}, J=3.5 \mathrm{~Hz}, \mathrm{H} 44^{\prime}\right), 5.79\left(4 \mathrm{H}, \mathrm{s}, \mathrm{CH}_{2}\right), 4.58\left(4 \mathrm{H}, \mathrm{s}, \mathrm{CH}_{2}\right) \cdot{ }^{13} \mathrm{C}$ 
NMR (75 MHz, DMSO) $\delta 178.40,154.65,152.41,144.05,124.48,123.97,112.35$, $62.63,45.74$.

\subsubsection{1,4-Bis\{[(1-((5-formylfuran-2-yl)methylene)-1H-1,2,3-triazole-4}

yl]methyleneoxy \}benzene (10). Compound $\mathbf{1 0}$ was prepared using the above mentioned procedure from 6 (150 mg, $0.81 \mathrm{mmol}$ ) to obtain 10 as white powder $(386.8 \mathrm{mg}, 98 \%$, m.p. $\left.=163-165{ }^{\circ} \mathrm{C}\right) .{ }^{1} \mathrm{H}$ NMR $(300 \mathrm{MHz}, \mathrm{DMSO}) \delta 9.57(2 \mathrm{H}, \mathrm{s}, \mathrm{CHO}), 8.28(2 \mathrm{H}, \mathrm{s}$, H5"), 7.53 (2H, d, $J=3.6 \mathrm{~Hz}, \mathrm{H} 3$ '), 6.96 (4H, s, Ph), 6.80 (2H, d, $J=3.5 \mathrm{~Hz}, \mathrm{H} 4$ '), 5.82 $\left(4 \mathrm{H}, \mathrm{s}, \mathrm{CH}_{2}\right), 5.08\left(2 \mathrm{H}, \mathrm{s}, \mathrm{CH}_{2}\right) .{ }^{13} \mathrm{C}$ NMR (75 MHz, DMSO) $\delta 178.40,154.59,152.43$, $152.28,143.29,124.86,123.99,115.60,112.42,61.40,45.78$.

\subsubsection{4,4'-Bis\{[1-(5-formylfuran-2-yl)methylene)-1H-1,2,3-triazole-4-}

yl]methyleneoxy\}-1,1'-biphenyl (11). Compound 11 was prepared using the above mentioned procedure from $7(150 \mathrm{mg}, 0.57 \mathrm{mmol})$ to obtain 11 as white powder (311.7 mg, 97\%, m.p. $\left.=216-218{ }^{\circ} \mathrm{C}\right) .{ }^{1} \mathrm{H}$ NMR (300 MHz, DMSO) $\delta 9.57(2 \mathrm{H}, \mathrm{s}, \mathrm{CHO}), 8.33$ (2H, s, H5"), 7.58-7.51 (6H, m, $J=6.0,5.1 \mathrm{~Hz}, \mathrm{H3}$; $\mathrm{Ph}), 7.09$ (4H, d, $J=8.8 \mathrm{~Hz}, \mathrm{Ph}$ ), $6.81(2 \mathrm{H}, \mathrm{d}, J=3.6 \mathrm{~Hz}, \mathrm{H} 4), 5.83\left(4 \mathrm{H}, \mathrm{s}, \mathrm{CH}_{2}\right), 5.19\left(4 \mathrm{H}, \mathrm{s}, \mathrm{CH}_{2}\right) .{ }^{13} \mathrm{C} \mathrm{NMR}(151 \mathrm{MHz}$, DMSO) $\delta 178.39,157.14,154.55,152.44,143.12,132.58,127.24,124.95,123.95$, $115.10,112.44,61.02,45.80$.

4.2.3. General procedure for the synthesis of compounds $13 \boldsymbol{a}-13 \boldsymbol{b}, 14 \boldsymbol{a}-14 c, 15 a-15 b$ and $16 a-16 e$

The reaction mixture of dimeric bis-triazolylfuraldehyde derivatives (8-11), ophenylenediamine (12a-12f) and water solution of $\mathrm{NaHSO}_{3}(40 \%, 1 \mathrm{~mL})$ was dissolved in $15 \mathrm{~mL}$ EtOH and stirred under reflux for $6-8 \mathrm{~h}$. After completition of the reaction $\mathrm{NaHSO}_{3}$ was filtered and the reaction mixture was evaporated to dryness. Water was added $(5 \mathrm{~mL})$ and the mixture was stirred over night and filtered. The crude residue was dissolved in $\mathrm{HCl}$ saturated $\mathrm{MeOH}(8-10 \mathrm{~mL})$ and stirred over night. Addition of ether resulted in precipitation of products $13 a-13 b, 14 a-14 c, 15 a-15 b$ and $16 a-16 e$.

4.2.3.1. 1,3-Bis\{1-[((5-(5-amidino)benzimidazol-2-yl)furan-2-yl)methylene]-1H-1,2,3triazole-4-ylspropane hydrochloride (13a). Compound 13a was prepared using the above 
described method from $8(150 \mathrm{mg}, 0.38 \mathrm{mmol})$ and $12 \mathrm{a}(155.8 \mathrm{mg}, 0.84 \mathrm{mmol})$ to obtain 13a as brown powder $\left(178.2 \mathrm{mg}, 55 \%\right.$, m.p. $\left.=197-200{ }^{\circ} \mathrm{C}\right) .{ }^{1} \mathrm{H}$ NMR $(300 \mathrm{MHz}$, DMSO) $\delta 9.34$ (2H, s, NH), 9.00 (2H, s, NH), 8.10 (2H, s, H4), 8.03 (2H, s, H5"), 7.75 (2H, d, $J=8.5 \mathrm{~Hz}, \mathrm{H} 7), 7.68$ (2H, dd, $J=8.4,1.3 \mathrm{~Hz}, \mathrm{H} 6), 7.40$ (2H, d, $J=3.4 \mathrm{~Hz}, \mathrm{H} 3$ '), $6.83\left(2 \mathrm{H}, \mathrm{d}, J=3.4 \mathrm{~Hz}, \mathrm{H} 4\right.$ '), $5.75\left(4 \mathrm{H}, \mathrm{s}, \mathrm{CH}_{2}\right), 2.68$ (4H, t, $\left.J=7.4 \mathrm{~Hz}, \mathrm{CH}_{2}\right), 1.99-1.87$ $\left(2 \mathrm{H}, \mathrm{m}, \mathrm{CH}_{2}\right){ }^{13} \mathrm{C}$ NMR $(75 \mathrm{MHz}, \mathrm{DMSO}) \delta 165.72,152.29,146.93,142.93,139.56$, 136.52, 123.42, 122.81, 122.40, 115.75, 115.66, 114.72, 112.86, 45.68, 28.61, 24.48. Anal. calcd. for $\mathrm{C}_{33} \mathrm{H}_{30} \mathrm{~N}_{14} \mathrm{O}_{2} \times 4 \mathrm{HCl} \times 1.1 \mathrm{H}_{2} \mathrm{O}(M r=820.35)$ : $\mathrm{C} 48.32, \mathrm{H} 4.45, \mathrm{~N}$ 23.90; found: C 48.14, H 4.79, N 24.02\%.

4.2.3.2. 1,3-Bis\{1-[((5-(5-N-isopropylamidino)benzimidazol-2-yl)furan-2-yl)methylene]1H-1,2,3-triazole-4-ylspropane hydrochloride (13b). Compound 13b was prepared using the above described method from $8(100 \mathrm{mg}, 0.25 \mathrm{mmol})$ and $\mathbf{1 2 b}(118.64 \mathrm{mg}, 0.56$ mmol) to obtain 13b as brown powder $\left(69.7 \mathrm{mg}, 30 \%\right.$, m.p. $\left.=258-261{ }^{\circ} \mathrm{C}\right) .{ }^{1} \mathrm{H}$ NMR (300 MHz, DMSO) $\delta 9.61(2 \mathrm{H}, \mathrm{d}, J=7.2 \mathrm{~Hz}, \mathrm{NH}), 9.47(2 \mathrm{H}, \mathrm{s}, \mathrm{NH}), 9.10(2 \mathrm{H}, \mathrm{s}, \mathrm{NH})$, 8.11 (2H, s, H4), 8.00 (2H, s, H5"), 7.77 (2H, d, J = 8.1 Hz, H7), 7.66-7.54 (4H, m, H6; H3'), $6.86\left(2 \mathrm{H}, \mathrm{s}, \mathrm{H} 4{ }^{\prime}\right), 5.77$ (4H, s, CH2), 4.19-3.97 (2H, m, CH), 2.67 (4H, t, $J=6.5 \mathrm{~Hz}$, $\left.\mathrm{CH}_{2}\right), 1.98-1.87(2 \mathrm{H}, \mathrm{m}, \mathrm{CH}), 1.29\left(12 \mathrm{H}, \mathrm{d}, J=5.9 \mathrm{~Hz}, \underline{\mathrm{CH}}_{3} \mathrm{CHCH}_{3}\right) .{ }^{13} \mathrm{C}$ NMR $(75$ MHz, DMSO) $\delta 162.04,151.65,146.82,144.69,143.67,123.60,123.06,122.22,115.78$, 114.54, 112.53, 69.67, 45.60, 44.96, 28.52, 24.39, 21.18. Anal. calcd. for $\mathrm{C}_{39} \mathrm{H}_{42} \mathrm{~N}_{14} \mathrm{O}_{2} \times$ $4 \mathrm{HCl} \times 0.7 \mathrm{H}_{2} \mathrm{O}(\mathrm{Mr}=897.31): \mathrm{C} 52.20, \mathrm{H} 5.32, \mathrm{~N} 21.85$; found: $\mathrm{C} 52.59, \mathrm{H} 5.61, \mathrm{~N}$ $21.66 \%$.

4.2.3.3. 1,3-Bis\{1-[((5-(5-imidazolin-2-yl)benzimidazol-2-yl)furan-2-yl)methylene]-1H1,2,3-triazole-4-ylspropane hydrochloride (13c). Compound $13 \mathbf{c}$ was prepared using the above described method from $8(150 \mathrm{mg}, 0.38 \mathrm{mmol})$ and $12 \mathrm{c}(192.12 \mathrm{mg}, 0.84 \mathrm{mmol})$ to obtain 13c as light brown powder (163.0 mg, 48\%, m.p. > $\left.250{ }^{\circ} \mathrm{C}\right) .{ }^{1} \mathrm{H}$ NMR $(300 \mathrm{MHz}$, DMSO) $\delta 10.80$ (4H, s, NH), 8.39 (2H, s, H5"), 8.09 (2H, s, H4), 7.94 (2H, dd, $J=8.6$, $1.4 \mathrm{~Hz}, \mathrm{H6}), 7.79$ (2H, d, $J=8.5 \mathrm{~Hz}, \mathrm{H} 7), 7.57$ (2H, d, $J=3.5 \mathrm{~Hz}, \mathrm{H3}$ ), $6.86(2 \mathrm{H}, \mathrm{d}, J=$ $3.4 \mathrm{~Hz}, \mathrm{H}_{4}$ ) $), 5.77$ (4H, s, $\left.\mathrm{CH}_{2}\right), 4.01\left(8 \mathrm{H}, \mathrm{s}, \underline{\mathrm{CH}}_{2} \mathrm{CH}_{2}\right), 2.68$ (4H, t, J=7.5 Hz, $\left.\mathrm{CH}_{2}\right), 1.95$ $\left(2 \mathrm{H}, \mathrm{dt}, J=14.6,7.3 \mathrm{~Hz}, \mathrm{CH}_{2}\right) \cdot{ }^{13} \mathrm{C}$ NMR (75 MHz, DMSO) $\delta 165.49,152.43,147.36$, $145.73,144.03,141.29,138.03,123.90,122.80,117.05,116.88,115.53,113.16,46.17$, 
44.72, 29.04, 24.93. Anal. calcd. for $\mathrm{C}_{37} \mathrm{H}_{34} \mathrm{~N}_{14} \mathrm{O}_{2} \times 4 \mathrm{HCl} \times 1.9 \mathrm{H}_{2} \mathrm{O}(M r=858.02)$ : $\mathrm{C}$ 51.79, H 4.53, N 22.85; found: C 51.96, H 4.74, N 22.63\%.

4.2.3.4. Bis\{1-[((5-(5-amidino)benzimidazol-2-yl)furan-2-yl)methylene]-1H-1,2,3triazole-4-ylsdimethylene ether hydrochloride (14a). Compound 14a was prepared using the above described method from $9(150 \mathrm{mg}, 0.38 \mathrm{mmol})$ and 12a $(141.8 \mathrm{mg}, 0.84 \mathrm{mmol})$ to obtain 14a as brown solid (69.4 mg, 22\%, m.p. $\left.>205{ }^{\circ} \mathrm{C}\right) .{ }^{1} \mathrm{H}$ NMR $(600 \mathrm{MHz}$, DMSO) $\delta 9.38$ (4H, s, NH), 9.09 (4H, s, NH), 8.29 (2H, s, H5"), 8.12 (2H, s, H4), 7.75 $(2 \mathrm{H}, \mathrm{d}, J=8.3 \mathrm{~Hz}, \mathrm{H} 7), 7.70$ (2H, d, $J=8.4 \mathrm{~Hz}, \mathrm{H} 6), 7.46$ (2H, d, $\left.J=3.1 \mathrm{~Hz}, \mathrm{H} 3{ }^{\prime}\right), 6.86$ $\left(2 \mathrm{H}, \mathrm{d}, J=3.3 \mathrm{~Hz}, \mathrm{H} 4^{\prime}\right), 5.81\left(4 \mathrm{H}, \mathrm{s}, \mathrm{CH}_{2}\right), 4.59\left(4 \mathrm{H}, \mathrm{s}, \mathrm{CH}_{2}\right) .{ }^{13} \mathrm{C}$ NMR $(75 \mathrm{MHz}$, DMSO) $\delta$ 165.90, 151.31, 145.36, 144.33, 144.10, 124.33, 122.65, 121.98, 114.04, 112.73, 62.69, 45.77. Anal. calcd. for $\mathrm{C}_{32} \mathrm{H}_{28} \mathrm{~N}_{14} \mathrm{O}_{3} \times 4 \mathrm{HCl} \times 0.5 \mathrm{H}_{2} \mathrm{O}(M r=811.51): \mathrm{C}$ 47.36, H 4.10, N 24.16; found: C 47.59, H 3.87, N 24.19\%. A232

4.2.3.5. Bis $\{1-[((5-(5-N-i s o p r o p y l a m i d i n o) b e n z i m i d a z o l-2-y l)$ furan-2-yl)methylene]-1H1,2,3-triazole-4-ylsdimethylene ether hydrochloride (14b). Compound $\mathbf{1 4 b}$ was prepared using the above described method from $9(150 \mathrm{mg}, 0.38 \mathrm{mmol})$ and $\mathbf{1 2 b}(168.82 \mathrm{mg}, 0.84$ mmol) to obtain $\mathbf{1 4 b}$ as grey powder $\left(134.2 \mathrm{mg}, 54 \%, \mathrm{~m} . \mathrm{p} .=217-221{ }^{\circ} \mathrm{C}\right) .{ }^{1} \mathrm{H}$ NMR $(600$ MHz, DMSO) $\delta 9.56(2 \mathrm{H}, \mathrm{d}, J=7.2 \mathrm{~Hz}, \mathrm{NH}), 9.43(2 \mathrm{H}, \mathrm{s}, \mathrm{NH}), 9.09$ (2H, s, NH), 8.32 (2H s, H5"), 8.00 (2H, s, H4), 7.73 (2H, d, $J=8.4 \mathrm{~Hz}, \mathrm{H} 7), 7.59$ (2H, dd, $J=8.6,1.1 \mathrm{~Hz}$, H6), $7.50\left(2 \mathrm{H}, \mathrm{d}, J=3.1 \mathrm{~Hz}, \mathrm{H} 3\right.$ '), $6.85\left(2 \mathrm{H}, \mathrm{d}, J=3.3 \mathrm{~Hz}, \mathrm{H} 4{ }^{\prime}\right), 5.81$ (4H, s, $\left.\mathrm{CH}_{2}\right), 4.60$ $\left(4 \mathrm{H}, \mathrm{s}, \mathrm{CH}_{2}\right), 4.18-4.11(2 \mathrm{H}, \mathrm{m}, \mathrm{CH}), 1.30\left(6 \mathrm{H}, \mathrm{d}, J=6.3 \mathrm{~Hz}, \underline{\mathrm{CH}}_{3} \mathrm{CHCH}_{3}\right) .{ }^{13} \mathrm{C} \mathrm{NMR}$ (151 MHz, DMSO) $\delta 162.16,151.28,145.03,144.26,144.08,134.06,124.38,123.42$, 122.89, 114.11, 112.62, 62.67, 45.74, 45.02, 21.27. Anal. calcd. for $\mathrm{C}_{38} \mathrm{H}_{40} \mathrm{~N}_{14} \mathrm{O}_{3} \times 4 \mathrm{HCl}$ $\times 0.2 \mathrm{H}_{2} \mathrm{O}(\mathrm{Mr}=820.18)$ : C 55.65, H 5.92, N 23.91; found: C 55.34, H 6.15, N 24.06\%.

4.2.3.6. 1,4-Bis\{[1-(((5-(5-amidino)benzimidazol-2-yl)furan-2-yl)methylene)-1H-1,2,3triazole-4-yl]methyleneoxy benzene hydrochloride (15a). Compound 15a was prepared using the above described method from 10 (100 $\mathrm{mg}, 0.20 \mathrm{mmol})$ and $12 \mathrm{a}(83.99 \mathrm{mg}, 0.45$ mmol) to obtain 15a as white powder $\left(158.2 \mathrm{mg}, 87 \%\right.$, m.p. $\left.=261-263{ }^{\circ} \mathrm{C}\right) .{ }^{1} \mathrm{H}$ NMR (600 MHz, DMSO) $\delta 9.41$ (4H, s, NH), 9.12 (4H, s, NH), 8.39 (2H, s, H5"), 8.14 (2H. s, H4), 7.79 (2H, d, $J=8.4 \mathrm{~Hz}, \mathrm{H} 7), 7.73(2 \mathrm{H}, \mathrm{d}, J=8.3 \mathrm{~Hz}, \mathrm{H} 6), 7.54(2 \mathrm{H}, \mathrm{d}, J=2.7 \mathrm{~Hz}$, 
H3'), 6.95 (4H, s, Ph), 6.90 (2H, d, J=3.0 Hz, H4'), 5.85 (4H, s, CH2), 5.06 (4H s, $\left.\mathrm{CH}_{2}\right) .{ }^{13} \mathrm{C}$ NMR (75 MHz, DMSO) $\delta 165.82,152.30,151.61,143.78,143.35,124.77$, 123.01, 122.38, 115.99, 115.58, 114.78, 112.93, 61.41, 45.82. Anal. calcd. for $\mathrm{C}_{38} \mathrm{H}_{32} \mathrm{~N}_{14} \mathrm{O}_{4} \times 4 \mathrm{HCl} \times 0.9 \mathrm{H}_{2} \mathrm{O}(M r=910.82): \mathrm{C} 50.11, \mathrm{H} 4.18, \mathrm{~N} \mathrm{22.11}$; found: $\mathrm{C}$ 49.81, H 4.22, N 22.03\%.

4.2.3.7. 1,4-Bis\{[1-(((5-(5-N-isopropylamidino)benzimidazol-2-yl)furan-2-yl)methylene)1H-1,2,3-triazole-4-yl]methyleneoxy\}benzene hydrochloride (15b). Compound 15b was prepared using the above described method from $10(100 \mathrm{mg}, 0.20 \mathrm{mmol})$ and $\mathbf{1 2 b}(76.33$ $\mathrm{mg}, 0.45 \mathrm{mmol})$ to obtain $\mathbf{1 5 b}$ as white powder $\left(121.7 \mathrm{mg}, 61 \%\right.$, m.p. $\left.=234-236{ }^{\circ} \mathrm{C}\right) .{ }^{1} \mathrm{H}$ NMR (600 MHz, DMSO) $\delta 9.59$ (2H, d, J= 7.9 Hz, NH), 9.46 (2H, s, NH), 9.08 (2H, s, $\mathrm{NH}), 8.41$ (2H, s, H5"), 8.01 (2H, s, H4), 7.78 (2H, d, J=8.5 Hz, H7), 7.61 (2H, dd, $J=$ 8.5, 1.1 Hz, H6), 7.57 (2H, d, $J=3.1 \mathrm{~Hz}, \mathrm{H} 3$ '), 6.96 (4H, s, Ph), 6.90 (2H, d, $J=3.3 \mathrm{~Hz}$, H4'), 5.85 (4H, s, $\left.\mathrm{CH}_{2}\right), 5.07\left(4 \mathrm{H}, \mathrm{s}, \mathrm{CH}_{2}\right), 4.10(2 \mathrm{H}, \mathrm{td}, J=13.0,6.4 \mathrm{~Hz}, \mathrm{CH}), 1.30$ $\left(12 \mathrm{H}, \mathrm{d}, J=6.4 \mathrm{~Hz}, \underline{\mathrm{CH}_{3}} \mathrm{CHCH}_{3}\right) .{ }^{13} \mathrm{C} \mathrm{NMR}(75 \mathrm{MHz}, \mathrm{DMSO}) \delta 162.16,152.32,151.59$, $144.76,143.82,143.35,124.81,123.82$, 123.26, 115.94, 115.61, 114.72, 112.93, 111.30, 61.43, 45.83, 45.09, 21.30. Anal. calcd. for $\mathrm{C}_{44} \mathrm{H}_{44} \mathrm{~N}_{14} \mathrm{O}_{4} \times 4 \mathrm{HCl} \times 1.2 \mathrm{H}_{2} \mathrm{O}(\mathrm{Mr}=$ 1000.38): C 52.83, H 5.08, N 19.60; found: C 53.05, H 5.07, N 19.47\%.

4.2.3.8. 1,4-Bis\{[1-(((5-(5-imidazolin-2-yl)benzimidazol-2-yl)furan-2-yl)methylene)-1H1,2,3-triazole-4-yl]methyleneoxy\}benzene hydrochloride (15c). Compound $\mathbf{1 5 c}$ was prepared using the above described method from 10 (100 $\mathrm{mg}, 0.20 \mathrm{mmol})$ and 12c (103.02 mg, $0.45 \mathrm{mmol}$ ) to obtain $15 \mathrm{c}$ as brown crystals $\left(93.6 \mathrm{mg}, 47 \%\right.$, m.p. $>250{ }^{\circ} \mathrm{C}$ ). ${ }^{1} \mathrm{H}$ NMR (300 MHz, DMSO) $\delta 10.61$ (4H, s, NH), 8.35 (2H, s, H5"), 8.31 (2H, s, H4), $7.84(2 \mathrm{H}, \mathrm{d}, J=8.5 \mathrm{~Hz}, \mathrm{H} 7), 7.77$ (2H, d, $J=8.0 \mathrm{~Hz}, \mathrm{H} 6), 7.40$ (2H, d, $J=3.2 \mathrm{~Hz}, \mathrm{H} 3$ '), $6.95(4 \mathrm{H}, \mathrm{s}, \mathrm{Ph}), 6.86(2 \mathrm{H}, \mathrm{d}, J=3.4 \mathrm{~Hz}, \mathrm{H} 4), 5.83\left(4 \mathrm{H}, \mathrm{s}, \mathrm{CH}_{2}\right), 5.06\left(4 \mathrm{H}, \mathrm{s}, \mathrm{CH}_{2}\right), 4.01$ $\left(8 \mathrm{H}, \mathrm{s}, \underline{\mathrm{CH}_{2} \mathrm{CH}_{2}}\right) .{ }^{13} \mathrm{C} \mathrm{NMR}(75 \mathrm{MHz}, \mathrm{DMSO}) \delta 165.31,152.29,150.95,146.19,144.99$, 143.31, 124.65, 122.65, 115.61, 115.56, 113.43, 112.72, 61.41, 45.83, 44.22. Anal. calcd. for $\mathrm{C}_{42} \mathrm{H}_{36} \mathrm{~N}_{14} \mathrm{O}_{4} \times 4 \mathrm{HCl} \times 2.8 \mathrm{H}_{2} \mathrm{O}(M r=997.12)$ : C 50.59, $\mathrm{H} 4.61, \mathrm{~N} 19.66$; found: $\mathrm{C}$ 50.82, H 4.43, N 19.75\%. 
4.2.3.9. 4,4'-Bis\{[1-(((5-(5-amidino)benzimidazol-2-yl)furan-2-yl)methylene)-1H-1,2,3triazole-4-yl]methyleneoxy\}-1,1'-biphenyl hydrochloride (16a). Compound 16a was prepared using the above described method from $11(150 \mathrm{mg}, 0.27 \mathrm{mmol})$ and 12a (108.25 mg, $0.58 \mathrm{mmol})$ to obtain 16a as white powder (181.7 mg, 31\%, m.p. $=260-263$ $\left.{ }^{\circ} \mathrm{C}\right) .{ }^{1} \mathrm{H}$ NMR (600 MHz, DMSO) $\delta 9.40(4 \mathrm{H}, \mathrm{s}, \mathrm{NH}), 9.11(4 \mathrm{H}, \mathrm{s}, \mathrm{NH}), 8.43(2 \mathrm{H}, \mathrm{s}$, H5"), 8.14 (2H, s, H4), 7.78 (2H, d, $J=8.5$ Hz, H7), $7.72(2 \mathrm{H}, \mathrm{d}, J=8.5 \mathrm{~Hz}, \mathrm{H} 6), 7.54-$ 7.48 (6H, m, Ph; H3'), 7.08 (4H, d, $J=8.6 \mathrm{~Hz}, \mathrm{Ph}), 6.90$ (2H, d, $\left.J=3.2 \mathrm{~Hz}, \mathrm{H} 4{ }^{\prime}\right), 5.86$ $\left(4 \mathrm{H}, \mathrm{s}, \mathrm{CH}_{2}\right), 5.19\left(4 \mathrm{H}, \mathrm{s}, \mathrm{CH}_{2}\right) .{ }^{13} \mathrm{C}$ NMR $(75 \mathrm{MHz}, \mathrm{DMSO}) \delta 165.86,157.14,151.42$, 144.11, 143.18, 132.54, 127.23, 124.89, 122.84, 122.20, 115.10, 114.39, 112.91, 61.04, 45.84. Anal. calcd. for $\mathrm{C}_{44} \mathrm{H}_{36} \mathrm{~N}_{14} \mathrm{O}_{4} \times 4 \mathrm{HCl} \times 1.5 \mathrm{H}_{2} \mathrm{O}(M r=997.73)$ : $\mathrm{C} 52.97, \mathrm{H}$ 4.34, N 19.65; found: C 53.18, H 4.22, N 19.97\%.

\subsubsection{4,4'-Bis\{[1-(((5-(5-N-isopropylamidino)benzimidazol-2-yl)furan-2-}

yl)methylene)-1H-1,2,3-triazole-4-yl]methyleneoxy\}-1,1'-biphenyl hydrochloride (16b).

Compound 16b was prepared using the above described method from 11 (70 mg, 0.12 mmol) and 12b (46.19 $\mathrm{mg}, 0.25 \mathrm{mmol}$ ) to obtain $\mathbf{1 6 b}$ as light brown powder ( $36.3 \mathrm{mg}$, $28 \%$, m.p. $\left.=236-238^{\circ} \mathrm{C}\right) .{ }^{1} \mathrm{H}$ NMR $(600 \mathrm{MHz}, \mathrm{DMSO}) \delta 9.56(2 \mathrm{H}, \mathrm{d}, J=7.6 \mathrm{~Hz}, \mathrm{NH})$, $9.42(2 \mathrm{H}, \mathrm{s}, \mathrm{NH}), 9.02(2 \mathrm{H}, \mathrm{s}, \mathrm{NH}), 8.43(2 \mathrm{H}, \mathrm{s}, \mathrm{H} 5 "), 7.99(2 \mathrm{H}, \mathrm{s}, \mathrm{H} 4), 7.76(2 \mathrm{H}, \mathrm{d}, J=$ $8.4 \mathrm{~Hz}, \mathrm{H} 7), 7.59(2 \mathrm{H}, \mathrm{d}, J=8.3 \mathrm{~Hz}, \mathrm{H} 6), 7.51(4 \mathrm{H}, \mathrm{d}, J=8.6 \mathrm{~Hz}, \mathrm{Ph}), 7.48(2 \mathrm{H}, \mathrm{d}, J=$ $\left.3.1 \mathrm{~Hz}, \mathrm{H} 3{ }^{\prime}\right), 7.08(4 \mathrm{H}, \mathrm{d}, J=8.6 \mathrm{~Hz}, \mathrm{Ph}), 6.89\left(2 \mathrm{H}, \mathrm{d}, J=3.2 \mathrm{~Hz}, \mathrm{H} 4{ }^{\prime}\right), 5.85(4 \mathrm{H}, \mathrm{s}$, $\left.\mathrm{CH}_{2}\right), 5.19\left(4 \mathrm{H}, \mathrm{s}, \mathrm{CH}_{2}\right), 4.08(2 \mathrm{H}, \mathrm{dt}, J=20.9,6.7 \mathrm{~Hz}, \mathrm{H}), 1.30(12 \mathrm{H}, \mathrm{d}, J=6.3 \mathrm{~Hz}$, $\left.\underline{\mathrm{CH}_{3}} \mathrm{CHCH}_{3}\right) .{ }^{13} \mathrm{C}$ NMR $(75 \mathrm{MHz}, \mathrm{DMSO}) \delta 162.42,157.24,151.24,145.35,144.57$, 143.26, 132.65, 127.34, 124.95, 123.53, 122.94, 116.23, 115.20, 114.90, 113.87, 112.96, 61.11, 45.93, 45.14, 21.35. Anal. calcd. for $\mathrm{C}_{50} \mathrm{H}_{48} \mathrm{~N}_{14} \mathrm{O}_{4} \times 4 \mathrm{HCl} \times 1.6 \mathrm{H}_{2} \mathrm{O}(\mathrm{Mr}=$ 1083.69): C 55.42, H 5.13, N 18.09; found: C 55.62, H 4.39, N 17.72\%.

\subsubsection{General procedure for the synthesis of compounds $\mathbf{1 4 c}$ and $\mathbf{1 6 c}$}

The reaction mixture of dimeric bis-triazolylfuraldehyde derivatives $(\mathbf{9}, \mathbf{1 1}), o$ phenylenediamine 12c (2eq) and p-benzoquinone (2 eq) was dissolved in $15 \mathrm{~mL} \mathrm{EtOH}$ and stirred under reflux for $6-8 \mathrm{~h}$. The reaction mixture was cooled at room temperature, diethyl ether was added, and the resulting solid was filtered off. 
4.2.4.1. Bis $\{1-[((5-(5-i m i d a z o l i n-2-y l)$ benzimidazol-2-yl)furan-2-yl)methylene]-1H-1,2,3triazole-4-ylsdimethylene ether hydrochloride (14c). Compound 14c was prepared using the above described method from 9 (100 $\mathrm{mg}, 0.25 \mathrm{mmol})$ and $12 \mathrm{c}(115.41 \mathrm{mg}, 0.50$ mmol) to obtain $14 \mathrm{c}$ as brown powder $\left(57.9 \mathrm{mg}, 26 \%\right.$, m.p. $\left.>250{ }^{\circ} \mathrm{C}\right) .{ }^{1} \mathrm{H}$ NMR (300 MHz, DMSO) $\delta 10.64$ (2H, bs, NH), 8.39-8.22 (4H, m, H4; H5"), 7.88-7.70 (4H, m, H7; H6), 7.39 (2H, d, $J=2.0 \mathrm{~Hz}, \mathrm{H} 3$ '), 6.84 (2H, d, $J=3.4 \mathrm{~Hz}, \mathrm{H} 4$ '), 5.80 (4H, s, $\left.\mathrm{CH}_{2}\right), 4.59$ (4H. s, $\left.\mathrm{CH}_{2}\right), 4.01\left(8 \mathrm{H}, \mathrm{s}, \underline{\mathrm{CH}}_{2} \mathrm{CH}_{2}\right) .{ }^{13} \mathrm{C}$ NMR (75 MHz, DMSO) $\delta 165.57,151.16$, 146.40, 145.03, 144.27, 124.47, 122.80, 115.81, 113.57, 112.86, 62.84, 45.94, 44.43. Anal. calcd. for $\mathrm{C}_{36} \mathrm{H}_{32} \mathrm{~N}_{14} \mathrm{O}_{3} \times 4 \mathrm{HCl} \times 2.7 \mathrm{H}_{2} \mathrm{O}(\mathrm{Mr}=903.23)$ : $\mathrm{C} 47.87, \mathrm{H} 4.62, \mathrm{~N}$ 21.11; found: C 48.78, H 4.56, N 21.10\%.

4.2.4.2. 4,4'-Bis\{[1-(((5-(5-imidazolin-2-yl)benzimidazol-2-yl)furan-2-yl)methylene)-1H1,2,3-triazole-4-yl]methyleneoxy\}-1,1'-biphenyl hydrochloride (16c). Compound 16c was prepared using the above described method from $11(150 \mathrm{mg}, 0.26 \mathrm{mmol})$ and $12 \mathrm{c}$ (133.69 mg, $0.58 \mathrm{mmol}$ ) to obtain $\mathbf{1 6 c}$ as white powder (79.1 mg, 29\%, m.p. $=246-248$ $\left.{ }^{\circ} \mathrm{C}\right) .{ }^{1} \mathrm{H}$ NMR (300 MHz, DMSO) $\delta 10.71(4 \mathrm{H}, \mathrm{s}, \mathrm{NH}), 8.44(2 \mathrm{H}, \mathrm{s}, \mathrm{H} 5 "), 8.36(2 \mathrm{H}, \mathrm{s}$, H4), 7.90 (2H, d, $J=8.0 \mathrm{~Hz}, \mathrm{H} 7), 7.80$ (2H, d, $J=8.4 \mathrm{~Hz}, \mathrm{H6}$ ), 7.53-7.43 (6H, m, Ph; H3'), 7.07 (4H, d, $J=8.4 \mathrm{~Hz}, \mathrm{Ph}), 6.89$ (2H, d, $J=2.8 \mathrm{~Hz}, \mathrm{H} 4$ '), $5.86\left(4 \mathrm{H}, \mathrm{s}, \mathrm{CH}_{2}\right), 5.18$ (4H, s, $\left.\mathrm{CH}_{2}\right), 4.01\left(8 \mathrm{H}, \mathrm{s}, \underline{\mathrm{CH}}_{2} \mathrm{CH}_{2}\right) .{ }^{13} \mathrm{C} \mathrm{NMR}(75 \mathrm{MHz}, \mathrm{DMSO}) \delta 165.18,157.08$, $151.17,144.47,143.13,132.49,127.15,124.79,122.93,116.80,115.89,115.59,115.07$, 114.01, 112.76, 61.02, 45.82, 44.20. Anal. calcd. for $\mathrm{C}_{48} \mathrm{H}_{40} \mathrm{~N}_{14} \mathrm{O}_{4} \times 4 \mathrm{HCl} \times 1.4 \mathrm{H}_{2} \mathrm{O}$ $(M r=1048.00):$ C 55.01, H 4.50, N 18.71; found: C 54.87, H 4.67, N 18.54\%.

4.2.5. General procedure for the synthesis of compounds $13 d-13 f, 14 d-14 f, 15 d-15 f$ and $16 d-16 f$

The reaction mixture of dimeric bis-triazolylfuraldehyde derivatives (8-11), ophenylenediamine (12d, 12e, 12f) and $40 \% \mathrm{NaHSO}_{3}$ was dissolved in $15 \mathrm{~mL}$ EtOH and stirred under reflux for 6-8 h. After completition of the reaction $\mathrm{NaHSO}_{3}$ was filtered and the reaction mixture was evaporated to dryness. Water was added $(5 \mathrm{~mL})$ and the mixture was stirred over night and filtered. The crude residue was dissolved in acetone addition of water resulted in precipitation of products $13 d-13 f, 14 d-14 f$, $15 d-15 f$ and $16 d-16 f$. 
4.2.5.1. 1,3-Bis\{1-[(5-(5-fluorobenzimidazol-2-yl)furan-2-yl)methylene]-1H-1,2,3-

triazol-4-ylspropane (13d). Compound 13d was prepared using the above described method from 8 (150 $\mathrm{mg}, 0.38 \mathrm{mmol})$ and $\mathbf{1 2 d}(105.95 \mathrm{mg}, 0.84 \mathrm{mmol})$ to obtain $\mathbf{1 3 d}$ as brown powder $\left(161.4 \mathrm{mg}, 70 \%\right.$, m.p. $\left.=146-149{ }^{\circ} \mathrm{C}\right) .{ }^{1} \mathrm{H}$ NMR $(600 \mathrm{MHz}, \mathrm{DMSO}) \delta$ 13.05 (2H, bs, NH), 7.96 (2H, s, H5"), 7.64-7.21 (4H, m, H4; H7), 7.18 (2H, s, H3'), 7.06 $(2 \mathrm{H}, \mathrm{s}, \mathrm{H} 6), 6.77(2 \mathrm{H}, \mathrm{d}, J=2.5 \mathrm{~Hz}, \mathrm{H} 4), 5.72\left(4 \mathrm{H}, \mathrm{s}, \mathrm{CH}_{2}\right), 2.67(4 \mathrm{H}, \mathrm{t}, J=7.3 \mathrm{~Hz}$, $\left.\mathrm{CH}_{2}\right), 1.95-1.89\left(2 \mathrm{H}, \mathrm{m}, \mathrm{CH}_{2}\right) .{ }^{13} \mathrm{C}$ NMR $(75 \mathrm{MHz}, \mathrm{DMSO}) \delta 160.32 ; 157.20\left(\mathrm{~d}, J_{C F}=\right.$ $235.8 \mathrm{~Hz}), 150.34,146.92,145.51,144.36,142.74,127.74,122.02,112.32,111.60$, $110.67 ; 110.31\left(, J_{C F}=27.0 \mathrm{~Hz}\right), 45.71,28.70,24.52$. Anal. calcd. for $\mathrm{C}_{31} \mathrm{H}_{24} \mathrm{~N}_{10} \mathrm{~F}_{2} \mathrm{O}_{2} \times$ $3.2 \mathrm{H}_{2} \mathrm{O}(M r=664.24)$ : C 56.05, H 4.61, N 21.09; found: C 56.17, H 4.73, N 21.21\%.

4.2.5.2. 1,3-Bis\{1-[(5-(5-chlorobenzimidazol-2-yl)furan-2-yl)methylene]-1H-1,2,3triazol-4-ylspropane (13e). Compound 13e was prepared using the above described method from 8 (150 $\mathrm{mg}, 0.38 \mathrm{mmol})$ and $\mathbf{1 2 e}(119.97 \mathrm{mg}, 0.84 \mathrm{mmol})$ to obtain 13e as brown powder $\left(61.9 \mathrm{mg}, 25 \%\right.$, m.p. $\left.=158-161{ }^{\circ} \mathrm{C}\right) .{ }^{1} \mathrm{H}$ NMR $(600 \mathrm{MHz}, \mathrm{DMSO}) \delta$ 13.43-12.79 (2H, m, NH), 7.97 (2H, s, H5"), 7.70-7.45 (4H, m, H4; H7), 7.21 (4H, d, $J=$ $\left.3.2 \mathrm{~Hz}, \mathrm{H} 6, \mathrm{H}^{\prime}\right), 6.79$ (2H, d, $\left.J=3.1 \mathrm{~Hz}, \mathrm{H}^{\prime}\right), 5.73\left(4 \mathrm{H}, \mathrm{s}, \mathrm{CH}_{2}\right), 2.67$ (4H, t, $J=7.4 \mathrm{~Hz}$, $\left.\mathrm{CH}_{2}\right), 1.93\left(2 \mathrm{H}, \mathrm{dt}, J=14.8,7.4 \mathrm{~Hz}, \mathrm{CH}_{2}\right) .{ }^{13} \mathrm{C} \mathrm{NMR}(75 \mathrm{MHz}, \mathrm{DMSO}) \delta 150.54$, 146.92, 145.34, 144.36, 122.62, 122.02, 112.38, 112.02, 45.70, 28.69, 24.52. Anal. calcd. for $\mathrm{C}_{31} \mathrm{H}_{24} \mathrm{~N}_{10} \mathrm{Cl}_{2} \mathrm{O}_{2} \times 2.2 \mathrm{H}_{2} \mathrm{O}(M r=679.13)$ : $\mathrm{C} 54.83, \mathrm{H} 4.21, \mathrm{~N} 20.62$; found: $\mathrm{C} 55.06$, H 4.36 , N 20.48\%.

4.2.5.3. 1,3-Bis\{1-[(5-(benzimidazol-2-yl)furan-2-yl)methylene]-1H-1,2,3-triazol-4$y$ lspropane (13f). Compound $\mathbf{1 3 f}$ was prepared using the above described method from $\mathbf{8}$ (130 $\mathrm{mg}, 0.33 \mathrm{mmol})$ and $\mathbf{1 2 f}(78.42 \mathrm{mg}, 0.72 \mathrm{mmol})$ to obtain $\mathbf{1 3 f}$ as yellow powder (185.8 mg, 99\%, m.p. $\left.=154-156{ }^{\circ} \mathrm{C}\right) .{ }^{1} \mathrm{H}$ NMR (300 MHz, DMSO) $\delta 7.96(2 \mathrm{H}, \mathrm{s}, \mathrm{H} 5 ")$, 7.65-7.46 (4H, m, J = 5.6, 3.0 Hz, H4; H7), 7.24-7.16 (6H, m, H5; H6; H3'), 6.77 (2H, d, $\left.J=3.1 \mathrm{~Hz}, \mathrm{H}^{\prime}\right), 5.72\left(4 \mathrm{H}, \mathrm{s}, \mathrm{CH}_{2}\right), 2.67\left(4 \mathrm{H}, \mathrm{t}, J=7.4 \mathrm{~Hz}, \mathrm{CH}_{2}\right), 2.03-1.81(2 \mathrm{H}, \mathrm{m}$, $\left.\mathrm{CH}_{2}\right) .{ }^{13} \mathrm{C}$ NMR (75 MHz, DMSO) $\delta 150.26,146.92,145.67,143.01,122.45,122.02$, 112.31, 111.50, 45.72, 28.70, 24.53. Anal. calcd. for $\mathrm{C}_{31} \mathrm{H}_{26} \mathrm{~N}_{10} \mathrm{O}_{2} \times 3.9 \mathrm{H}_{2} \mathrm{O}(M r=$ 639.07): C 58.26, H 5.30, N 21.92; found: C 58.00, H 5.53, N 22.24\%. 
4.2.5.4. Bis\{1-[(5-(5-fluorobenzimidazol-2-yl)furan-2-yl)methylene]-1H-1,2,3-triazol-4$y l$ l'dimethylene ether $(\mathbf{1 4 d})$. Compound $\mathbf{1 4 d}$ was prepared using the above described method from 9 (145 $\mathrm{mg}, 0.37 \mathrm{mmol})$ and $\mathbf{1 2 d}(96.90 \mathrm{mg}, 0.77 \mathrm{mmol})$ to obtain $\mathbf{1 4 d}$ as yellow powder (187.4 mg, 84\%, m.p. $=162-165^{\circ} \mathrm{C} .{ }^{1} \mathrm{H}$ NMR $(300 \mathrm{MHz}, \mathrm{DMSO}) \delta 8.21$ (2H, s, H5"), 7.55 (2H, dd, $J=8.8,4.8 \mathrm{~Hz}, \mathrm{H} 4), 7.36$ (2H, dd, $J=9.4,2.3 \mathrm{~Hz}, \mathrm{H} 7), 7.20$ $(2 \mathrm{H}, \mathrm{d}, J=3.4 \mathrm{~Hz}, \mathrm{H} 3$ ') 7.07 (2H, td, $J=9.9,2.4 \mathrm{~Hz}, \mathrm{H} 6), 6.80$ (2H, d, $J=3.4 \mathrm{~Hz}, \mathrm{H} 4$ '), $5.77\left(4 \mathrm{H}, \mathrm{s}, \mathrm{CH}_{2}\right), 4.59\left(4 \mathrm{H}, \mathrm{s}, \mathrm{CH}_{2}\right) .{ }^{13} \mathrm{C}$ NMR (151 MHz, DMSO) $\delta 159.60 ; 158.03$ (d, $\left.J_{C F}=235.9 \mathrm{~Hz}\right), 150.31,145.18,144.08,124.12,112.49,111.94,110.76 ; 110.59\left(\mathrm{~d}, J_{C F}\right.$ $=25.5 \mathrm{~Hz}), 62.71$, 45.76. Anal. calcd. for $\mathrm{C}_{30} \mathrm{H}_{22} \mathrm{~N}_{10} \mathrm{~F}_{2} \mathrm{O}_{3} \times 0.1 \mathrm{H}_{2} \mathrm{O}(M r=612.21): \mathrm{C}$ 58.86, H 3.64, N 22.88; found: C 58.62, H 3.35, N 23.00\%.

4.2.5.5. Bis\{1-[(5-(5-chlorobenzimidazol-2-yl)furan-2-yl)methylene]-1H-1,2,3-triazol-4yl\}dimethylene ether $(\mathbf{1 4} \boldsymbol{e})$. Compound $14 \mathrm{e}$ was prepared using the above described method from $9(150 \mathrm{mg}, 0.38 \mathrm{mmol})$ and $12 \mathrm{e}(113.31 \mathrm{mg}, 0.79 \mathrm{mmol})$ to obtain $14 \mathrm{e}$ as yellow powder (235.1 mg, 96\%, m.p. $=144-147^{\circ} \mathrm{C} .{ }^{1} \mathrm{H}$ NMR (300 MHz, DMSO) $\delta 8.20$ (2H, s, H5"), 7.62-7.51 (4H, m, H4; H7), 7.24-7.19 (4H, m, H6; H3'), 6.80 (2H, d, J= $3.4 \mathrm{~Hz}, \mathrm{H} 4)$ ), $5.77\left(4 \mathrm{H}, \mathrm{s}, \mathrm{CH}_{2}\right), 4.59\left(4 \mathrm{H}, \mathrm{s}, \mathrm{CH}_{2}\right) .{ }^{13} \mathrm{C} \mathrm{NMR}(75 \mathrm{MHz}, \mathrm{DMSO}) \delta 150.33$, 145.39, 144.30, 144.09, 126.62, 124.15, 122.61, 112.52, 112.02, 62.71, 45.78. Anal. calcd. for $\mathrm{C}_{30} \mathrm{H}_{22} \mathrm{~N}_{10} \mathrm{Cl}_{2} \mathrm{O}_{3} \times 0.4 \mathrm{H}_{2} \mathrm{O}(M r=656.06)$ : C 54.92, H 3.44, N 21.35; found: $\mathrm{C}$ $55.16, \mathrm{H} 3.59$, N $21.42 \%$.

4.2.5.6. Bis\{1-[(5-(benzimidazol-2-yl)furan-2-yl)methylene]-1H-1,2,3-triazol-4$y l$; dimethylene ether (14f). Compound $\mathbf{1 4 f}$ was prepared using the above described method from $9(150 \mathrm{mg}, 0.38 \mathrm{mmol})$ and $\mathbf{1 2 f}(85.43 \mathrm{mg}, 0.79 \mathrm{mmol})$ to obtain $\mathbf{1 4 f}$ as yellow powder (180.2 mg, 87\%, m.p. $=227-231{ }^{\circ} \mathrm{C} .{ }^{1} \mathrm{H}$ NMR (300 MHz, DMSO) $\delta$ 12.94 (2H, bs, NH), 8.21 (2H, s, H5"), 7.57-7.49 (4H, m, H4; H7), 7.25- 7.13 (6H, m, $\mathrm{H} 5$; H6; H3'), $6.79(2 \mathrm{H}, \mathrm{d}, J=3.4 \mathrm{~Hz}, \mathrm{H} 4), 5.77\left(4 \mathrm{H}, \mathrm{s}, \mathrm{CH}_{2}\right), 4.59\left(4 \mathrm{H}, \mathrm{s}, \mathrm{CH}_{2}\right) .{ }^{13} \mathrm{C}$ NMR (75 MHz, DMSO) $\delta 149.97,145.87,144.10,143.02,124.15,122.37,112.43$, 111.35, 62.73, 45.81. Anal. calcd. for $\mathrm{C}_{30} \mathrm{H}_{24} \mathrm{~N}_{10} \mathrm{O}_{3} \times 3.2 \mathrm{H}_{2} \mathrm{O}(M r=632.04): \mathrm{C} 57.01, \mathrm{H}$ 4.88, N 22.16; found: C 56.74, H 4.96, N 22.15\%. 
4.2.5.7. 1,4-Bis\{[1-((5-(5-fluorobenzimidazol-2-yl)furan-2-yl)methylene)-1H-1,2,3triazol-4-yl]methyleneoxy\}benzene (15d). Compound 15d was prepared using the above described method from $10(150 \mathrm{mg}, 0.31 \mathrm{mmol})$ and $\mathbf{1 2 d}(77.45 \mathrm{mg}, 0.68 \mathrm{mmol})$ to obtain 15d as light brown powder (195.4 mg, 90\%, m.p. $\left.=152-154{ }^{\circ} \mathrm{C}\right) .{ }^{1} \mathrm{H}$ NMR $(300$ MHz, DMSO) $\delta 8.29$ (2H, s, H5"), 7.55 (2H, dd, $J=8.5,4.7 \mathrm{~Hz}, \mathrm{H} 4), 7.35$ (2H, dd, $J=$ 9.2, $1.7 \mathrm{~Hz}, \mathrm{H} 7), 7.20(2 \mathrm{H}, \mathrm{d}, J=3.1 \mathrm{~Hz}, \mathrm{H} 3$ '), 7.06 (2H, td, $J=9.3,1.6 \mathrm{~Hz}, \mathrm{H6}), 6.95$ (4H, s, Ph), $6.82(2 \mathrm{H}, \mathrm{d}, J=3.1 \mathrm{~Hz}, \mathrm{H} 4), 5.80\left(4 \mathrm{H}, \mathrm{s}, \mathrm{CH}_{2}\right), 5.06\left(4 \mathrm{H}, \mathrm{s}, \mathrm{CH}_{2}\right) .{ }^{13} \mathrm{C} \mathrm{NMR}$ $(151 \mathrm{MHz}, \mathrm{DMSO}) \delta 159.61 ; 158.05\left(\mathrm{~d}, J_{C F}=235.4 \mathrm{~Hz}\right), 152.31,150.22,145.49$, 144.30, 143.35, 124.62, 115.58, 112.63, 111.80, 110.72; 110.56 (d, $\left.J_{C F}=24.2 \mathrm{~Hz}\right), 61.42$, 45.88. Anal. calcd. for $\mathrm{C}_{36} \mathrm{H}_{26} \mathrm{~F}_{2} \mathrm{~N}_{10} \mathrm{O}_{4} \times 1.6 \mathrm{H}_{2} \mathrm{O}(M r=729.49)$ : $\mathrm{C} 59.27, \mathrm{H} 4.03, \mathrm{~N}$ 19.20; found: C 59.47, H 3.76, N 19.19\%.

4.2.5.8. 1,4-Bis\{[1-((5-(5-chlorobenzimidazol-2-yl)furan-2-yl)methylene)-1H-1,2,3triazol-4-yl]methyleneoxy\}benzene (15d). (15e). Compound 15e was prepared using the above described method from $10(150 \mathrm{mg}, 0.31 \mathrm{mmol})$ and $12 \mathrm{e}(51.62 \mathrm{mg}, 0.68 \mathrm{mmol})$ to obtain 15e as white powder $\left(135.3 \mathrm{mg}, 60 \%\right.$, m.p. $\left.=160-162{ }^{\circ} \mathrm{C}\right) .{ }^{1} \mathrm{H}$ NMR $(300 \mathrm{MHz}$, DMSO) $\delta 8.29$ (2H, s, H5"), 7.66-7.52 (4H, m, H4; H/), 7.25-7.20 (4H, m, H6; H3'), 6.95 (4H. s, Ph), 6.83 (2H, d, J=3.4 Hz, H4'), $5.81\left(4 \mathrm{H} . \mathrm{s}, \mathrm{CH}_{2}\right), 5.06\left(4 \mathrm{H}, \mathrm{s}, \mathrm{CH}_{2}\right) .{ }^{13} \mathrm{C}$ NMR (75 MHz, DMSO) $\delta 152.29,150.40,145.25,143.32,126.74,124.54,122.73$, 115.56, 112.63, 112.22, 61.42, 45.83. Anal. calcd. for $\mathrm{C}_{36} \mathrm{H}_{26} \mathrm{Cl}_{2} \mathrm{~N}_{10} \mathrm{O}_{4} \times 0.9 \mathrm{H}_{2} \mathrm{O}(M r=$ 749.79): C 57.67, H 3.74, N 18.68; found: C 57.95, H 3.71, N 18.53\%.

4.2.5.9. 1,4-Bis\{[1-((5-(benzimidazol-2-yl)furan-2-yl)methylene)-1H-1,2,3-triazol-4yl]methyleneoxy ;benzene (15f). Compound $\mathbf{1 5 f}$ was prepared using the above described method from $10(150 \mathrm{mg}, 0.31 \mathrm{mmol})$ and $\mathbf{1 2 f}(73.06 \mathrm{mg}, 0.68 \mathrm{mmol})$ to obtain $\mathbf{1 5 f}$ as white powder (196.7 mg, 95\%, m.p. $\left.=155-157^{\circ} \mathrm{C}\right) .{ }^{1} \mathrm{H}$ NMR $(600 \mathrm{MHz}, \mathrm{DMSO}) \delta 8.30$ (2H, s, H5"), 7.55 (4H, s, H4; H7), 7.21-7.18 (6H, m, H6; H5; H3'), 6.95 (4H, s, $\mathrm{CH}_{2}$ ), $6.81(2 \mathrm{H}, \mathrm{d}, J=3.0 \mathrm{~Hz}, \mathrm{H} 4)$ ) $5.80\left(4 \mathrm{H} . \mathrm{s}, \mathrm{CH}_{2}\right), 5.06\left(4 \mathrm{H}, \mathrm{s}, \mathrm{CH}_{2}\right) .{ }^{13} \mathrm{C} \mathrm{NMR}(75 \mathrm{MHz}$, DMSO) $\delta$ 152.30, 149.96, 145.89, 143.33, 124.54, 122.41, 115.58, 112.52, 111.40, 61.44, 45.87. Anal. calcd. for $\mathrm{C}_{36} \mathrm{H}_{28} \mathrm{Cl}_{2} \mathrm{~N}_{10} \mathrm{O}_{4} \times 3.1 \mathrm{H}_{2} \mathrm{O}(\mathrm{Mr}=720.53)$ : $\mathrm{C} 60.01, \mathrm{H} 4.78, \mathrm{~N}$ 19.43; found: C 59.86, H 4.61, N 19.38\%. 
4.2.5.10. 4,4'-Bis\{[1-((5-(5-fluorobenzimidazol-2-yl)furan-2-yl)methylene)-1H-1,2,3triazol-4-yl]methylenoxy\}-1,1'-biphenyl (16d). Compound 16d was prepared using the above described method from 11 (150 $\mathrm{mg}, 0.26 \mathrm{mmol})$ and $\mathbf{1 2 d}(67.03 \mathrm{mg}, 0.52 \mathrm{mmol})$ to obtain 16d as light brown powder $\left(120.5 \mathrm{mg}, 53 \%\right.$, m.p. $\left.=175-179{ }^{\circ} \mathrm{C}\right) .{ }^{1} \mathrm{H}$ NMR $(300$ MHz, DMSO) $\delta 13.06(2 \mathrm{H}, \mathrm{s}, \mathrm{NH}), 8.35$ (2H, s, H5"), 7.65-7.59 (2H, m, H4), 7.50 (4H, d, $J=8.6 \mathrm{~Hz}, \mathrm{Ph}), 7.41(2 \mathrm{H}, \mathrm{d}, J=9.9 \mathrm{~Hz}, \mathrm{H} 7), 7.28(2 \mathrm{H}, \mathrm{dd}, J=8.6,3.0 \mathrm{~Hz}, \mathrm{H} 6), 7.21-$ $7.17\left(2 \mathrm{H}, \mathrm{m}, \mathrm{H} 3\right.$ ') 7.07 (4H, d, J = 8.6 Hz, Ph), $6.82\left(2 \mathrm{H}, \mathrm{s}, \mathrm{H} 4{ }^{\prime}\right), 5.81$ (4H, s, $\left.\mathrm{CH}_{2}\right), 5.18$ $\left(4 \mathrm{H}, \mathrm{s}, \mathrm{CH}_{2}\right) .{ }^{13} \mathrm{C}$ NMR $(75 \mathrm{MHz}, \mathrm{DMSO}) \delta 157.03,153.85,149.84,145.54,143.06$, $132.49,131.27,128.43,127.01,124.28,115.03,112.24,111.32,61.10,45.75$. Anal. calcd. for $\mathrm{C}_{42} \mathrm{H}_{30} \mathrm{~F}_{2} \mathrm{~N}_{10} \mathrm{O}_{4} \times 5.1 \mathrm{H}_{2} \mathrm{O}(M r=868.64)$ : C 58.07, $\mathrm{H} 4.66, \mathrm{~N} 16.12$; found: $\mathrm{C}$ $57.85, \mathrm{H} 4.64$, N $16.26 \%$.

4.2.5.11. 4,4'-Bis\{[1-((5-(5-chlorobenzimidazol-2-yl)furan-2-yl)methylene)-1H-1,2,3triazol-4-yl]methyleneoxy\}-1,1'-biphenyl (16e). Compound 16e was prepared using the above described method from 11 (160 $\mathrm{mg}, 0.28 \mathrm{mmol})$ and $\mathbf{1 2 e}(88.91 \mathrm{mg}, 0.62 \mathrm{mmol})$ to obtain 16e as white powder $\left(120.5 \mathrm{mg}, 53 \%\right.$, m.p. $\left.=173-176{ }^{\circ} \mathrm{C}\right) .{ }^{1} \mathrm{H}$ NMR $(300 \mathrm{MHz}$, DMSO) $\delta 13.12$ (2H, d, $J=14.5 \mathrm{~Hz}, \mathrm{NH}), 8.35$ (2H, s, H5"), 7.66-7.60 (2H, m, H4), 7.57-7.44 (6H, m, H7; Ph), 7.29-7.18 (4H, m, H6; H3'), 7.07 (4H, d, J=8.4 Hz, Ph), $6.83(2 \mathrm{H}, \mathrm{d}, J=3.0 \mathrm{~Hz}, \mathrm{H} 4), 5.82\left(4 \mathrm{H}, \mathrm{s}, \mathrm{CH}_{2}\right), 5.18\left(4 \mathrm{H}, \mathrm{s}, \mathrm{CH}_{2}\right) .{ }^{13} \mathrm{C} \mathrm{NMR}(151 \mathrm{MHz}$, DMSO) $\delta 157.15,150.34,145.52,144.55,143.18,142.42,132.55,127.25,127.11$, $126.30,124.78,122.97,120.14,118.24,115.10,112.68,111.17,61.03,45.89$. Anal. calcd. for $\mathrm{C}_{42} \mathrm{H}_{30} \mathrm{Cl}_{2} \mathrm{~N}_{10} \mathrm{O}_{4} \times 4.3 \mathrm{H}_{2} \mathrm{O}(M r=887.13)$ : C 56.86, $\mathrm{H} 4.38, \mathrm{~N} 15.79$; found: $\mathrm{C}$ 56.66, H 4.64, N 15.56\%.

4.2.5.12. 4,4'-Bis\{[1-((5-(benzimidazol-2-yl)furan-2-yl)methylene)-1H-1,2,3-triazol-4-

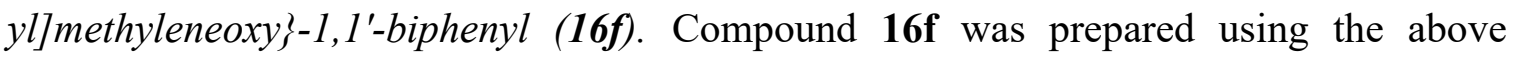
described method from 11 (100 $\mathrm{mg}, 0.18 \mathrm{mmol})$ and 12ef $(42.14 \mathrm{mg}, 0.39 \mathrm{mmol})$ to obtain 16f as light brown powder (120.14 mg, 90\%, m.p. $\left.=171-173{ }^{\circ} \mathrm{C}\right) .{ }^{1} \mathrm{H}$ NMR $(600$ MHz, DMSO) $\delta 8.37$ (2H, s, H5"), 7.59-7.56 (4H, m, H4; H7), 7.49 (4H, d, $J=8.6 \mathrm{~Hz}$, $\mathrm{Ph}), 7.23-7.21$ (6H, m, H5; H6; H3'), 7.07 (4H, d, $J=8.7 \mathrm{~Hz}, \mathrm{Ph}), 6.84$ (2H, d, $J=3.2$ $\left.\mathrm{Hz}, \mathrm{H} 4^{\prime}\right), 5.82\left(4 \mathrm{H}, \mathrm{s}, \mathrm{CH}_{2}\right), 5.18\left(4 \mathrm{H}, \mathrm{s}, \mathrm{CH}_{2}\right) .{ }^{13} \mathrm{C} \mathrm{NMR}(75 \mathrm{MHz}, \mathrm{DMSO}) \delta 157.13$, $150.21,145.45,143.18,136.67,132.54,127.21,124.72,122.69,115.09,112.64,112.48$, 
111.89, 61.05, 45.89. Anal. calcd. for $\mathrm{C}_{42} \mathrm{H}_{32} \mathrm{~N}_{10} \mathrm{O}_{4} \times 3.3 \mathrm{H}_{2} \mathrm{O}(M r=800.23): \mathrm{C} 63.04, \mathrm{H}$ 4.86, N 17.50; found: C 62.85, H 4.64, N 17.62\%.

\subsection{Spectroscopic experiments}

\subsubsection{Polynucleotides}

Poly A-poly U and calf thymus DNA ( $c t$ DNA) were purchased from Sigma-Aldrich. Polynucleotides were dissolved in PBS buffer, $I=0.05 \mathrm{~mol} \mathrm{dm}^{-3}, \mathrm{pH}$ 7.0. The calf thymus $c t$ DNA was additionally sonicated and filtered through a $0.45 \mathrm{~mm}$ filter. The polynucleotide concentration was spectroscopically determined as the concentration of nucleobases [50].

\subsubsection{UV-Visible Spectroscopy}

All UV-visible absorbance measurements were conducted on a Perkin Elmer Lambda 25 spectrophotometer. A quartz cell with a $1 \mathrm{~cm}$ path length was used for all absorbance studies. Compound stock solutions were $1 \mathrm{mM}$. The DNA/RNA at increasing ratios was then titrated into the compound buffer solution $\left(0.6-1.5 \cdot 10^{-5} \mathrm{~mol} \mathrm{dm}^{-3}\right)$ and the corresponding absorption spectra were recorded under the same conditions. All data were graphed and analyzed using Origin software 9.0. The stability constants (Ks) and [bound compound]/[polynucleotide phosphate] ratio (n) were calculated according to the Scatchard equation [51,52]. Values for Ks and $\mathrm{n}$ are given in Table 1; all have satisfying correlation coefficients ( 0.99$)$.

\subsubsection{Thermal Melting $\left(T_{m}\right)$}

Tm experiments were conducted with a Perkin Elmer Lambda 25 spectrophotometer in $1 \mathrm{~cm}$ quartz cuvettes. The absorbance of the DNA-compound complex was monitored at $260 \mathrm{~nm}$ as a function of temperature. The absorbance of the ligands was subtracted from every curve, and the absorbance scale was normalized. The $\Delta T_{m}$ values were calculated by subtracting $\mathrm{Tm}$ of the free nucleic acid from Tm of the complex. Every reported $\Delta T_{m}$ value was the average of at least two measurements. The error of $\Delta T_{m}$ is $\pm 0.5^{\circ} \mathrm{C}$. All data was graphed and analyzed using Origin software 9.0. 


\subsubsection{Circular Dichroism(CD)}

The CD spectra of DNA/RNA (concentration in cuvette $2 \cdot 10^{-5} \mathrm{M}$ ) were recorded with a JASCO J-800 spectrometer at different ratios $\mathrm{r}=0.1,0.3,0.5,0.7(\mathrm{r}=$ [compound]/ [polynucleotide]) at $25^{\circ} \mathrm{C}$ in aqueous buffer solution ( $\mathrm{pH}=7, \mathrm{PBS}, I=0.05$

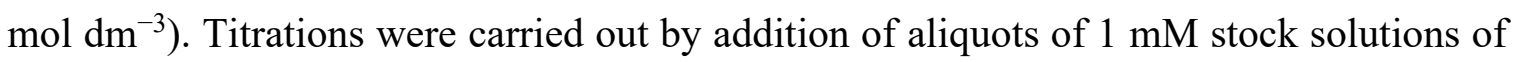
the relevant compound (at increasing ratios) to the buffered polynucleotide (DNA/RNA) solution in a $1 \mathrm{~cm}$ quartz cuvette and scanned over a wavelength range $220-450 \mathrm{~nm}$. All data were graphed and analyzed using Origin software 9.0.

\subsection{Antitrypanosomal screening}

Bloodstream form T. brucei (strain 221) were grown in modified Iscove's medium, as described [53] and growth inhibition assays were performed using 96-well microtiter plates. The compound concentrations that inhibited growth by 50\% ( $\left.\mathrm{IC}_{50}\right)$ and $90 \%$ (IC 90 ) were determined. Parasites were initially sub-cultured at $2.5 \times 10^{4} \mathrm{~mL}^{-1}$, compounds were added at range of concentrations, and the plates incubated at $37^{\circ} \mathrm{C}$. Resazurin was added after $48 \mathrm{~h}$, the plates incubated for a further 16 hours, and then read in a Spectramax plate reader. The data were analysed using GraphPad Prism. Each drug concentration was tested in triplicate.

For cytotoxicity assays, L6 cells (a rat myoblast line) were seeded into 96-well microtiter plates at $1 \times 10^{4} \mathrm{~mL}^{-1}$ in $200 \mu \mathrm{L}$ of growth medium, and different compound concentrations were added. The plates were then incubated for 6 days at $37^{\circ} \mathrm{C}$ and $20 \mu \mathrm{L}$ resazurin added to each well. After further 8 hours incubation, the fluorescence was determined using a Spectramax plate reader, as outlined above.

\subsection{In silico molecular modelling}

Interactions between 15c and DNA were studied using two different nucleotides: Drew-Dickerson dodecamer (12 bp DNA) d[(CGCGAATTCGCG)]2 encoded in Protein Data Bank (PDB) [54] as 1BNA [55] and the 14 bp B-DNA $\mathrm{d}[(\mathrm{CTACCGATAAGCAG})]_{2}$ extracted from the crystalographically determined structure of the complex between DNA and RNA polymerase (pdb: 5XOG) [56]. The ligand was 
accommodated into the ds-DNA minor groove visually by using the program InsightII. The AMBER ff14SB force field [57] and the general AMBER force field gaff [58] were used to parameterize the ligand-DNA complexes. Geometry optimization and molecular dynamics (MD) simulations were accomplished by using the AMBER16 program package [59]. The simulation was accomplished by using periodic boundary conditions (PBC). The particle mesh Ewald (PME) method was used for calculation of the longrange electrostatic interactions, and in the direct space the pairwise interactions were calculated within the cut-off distance of $10 \AA$. Each of the complexes were placed in the center of a octahedron filled with TIP3P-type water molecules, and $\mathrm{Cl}^{-}$and $\mathrm{Na}^{+}$ions were added to neutralize the systems. The solvated complexes were geometry optimized by using steepest descent and conjugate gradient methods, 1500 steps of each, and equilibrated for $1.5 \mathrm{~ns}$. During the first stage of equilibration ( $30 \mathrm{ps}$ ) the temperature was linearly increased from 0 to $300 \mathrm{~K}$ and the volume was held constant. In the second stage temperature and pressure were held fixed ( $300 \mathrm{~K}$ and $1 \mathrm{~atm}$, respectively) and the solution density was optimized. The equilibrated $15 \mathrm{c}-$ DNA complexes were subjected to productive molecular dynamics simulation using NPT condition and the time step of $2 \mathrm{fs}$, except SHAKE (constrains bonds involving hydrogen atoms) [60] no restraints were used. In the case of the $15 \mathrm{c}$ complex with $14 \mathrm{bp} 70 \mathrm{~ns}$ and in the case of the complex with dodecamer $160 \mathrm{~ns}$ of the productive MD simulations was accomplished. The temperature was held constant using Langevin thermostat [61] with a collision frequency of $1 \mathrm{ps}^{-1}$. Pressure was regulated by a Berendsen barostat [62].

\section{Declaration of interest}

Declaration of interest: none.

\section{Acknowledgment}

We greatly appreciate the financial support of the Croatian Science Foundation (project No. IP-2018-01-4682).

\section{References}


[1] D.H. Molyneux, Neglected tropical diseases: now more than just 'other diseases'-the post-2015 agenda. Int. Health. 6 (2014) 172-180. doi: 10.1093/inthealth/ihu037.

[2] Centers for Disease Control and Prevention, Neglected Tropical Diseases. http:/www.cdc.gov/globalhealth/ntd/, 2016 (accesed 15 June 2016)

[3] M. Njoroge, N.M. Njuguna, P. Mutai, D.S. Ongarora, P.W. Smith, K. Chibale, Recent approaches to chemical discovery and development against malaria and the neglected tropical diseases human African trypanosomiasis and schistosomiasis. Chem. Rev. 114 (2014) 11138-11163. doi: 10.1021/cr500098f.

[4] I. Sola, A. Artigas, M.C. Taylor, F.J. Pérez-Areales, E. Viayna, M.V. Clos, B. Pérez, C.W. Wright, J.M. Kelly, D. Muñoz-Torrero, Synthesis and biological evaluation of N-cyanoalkyl-, N-aminoalkyl-, and N-guanidinoalkyl-substituted 4-aminoquinoline derivatives as potent, selective, brain permeable antitrypanosomal agents. Bioorg. Med. Chem. 24 (2016) 5162-5171. doi: 10.1016/j.bmc.2016.08.036.

[5] M.P. Barrett, C.G. Gemmell, C.J. Suckling, Minor groove binders as antiinfective agents. Pharmacol. Ther. 139 (2013) 12-23. doi: 10.1016/j.pharmthera.2013.03.002.

[6] P.G. Bray, M.P. Barrett, S.A. Ward, H.P. de Koning, Pentamidine uptake and resistance in pathogenic protozoa: past, present and future. Trends Parasitol. 19 (2003) 232-239. doi: 10.1016/S1471-4922(03)00069-2.

[7] S. Kuriakose, J.E. Uzonna, Diminazene aceturate (Berenil), a new use for an old compound. Int. Immunopharmacol. 21 (2014) 342-345. doi: 10.1016/j.intimp.2014.05.027.

[8] B. Bouteille, O. Oukem, S. Bisser, M. Dumas, Treatment perspectives for human African trypanosomiasis. Fundam. Clin. Pharmacol. 17 (2003) 171-181. doi: 10.1046/j.1472-8206.2003.00167.x.

[9] R.P. Bakshi, T.A. Shapiro, DNA topoisomerases as targets for antiprotozoal therapy. Mini Rev. Med. Chem. 3 (2003) 597-608. doi: $10.2174 / 1389557033487863$. 
[10] R.R. Tidwell, D.W. Boykin, Dicationic DNA minor groove binders as antimicrobial agents, in M. Demeunynck, C. Bailly, W.D. Wilson, (Eds.), DNA and RNA binders: From small molecules to drugs, WILEY-VCH; Weinheim, 2003. Vol. 2, pp. 414-460.

[11] V. Delespaux, H.P. de Koning, Drugs and drug resistance in African trypanosomiasis. Drug Resist. Updat. 10 (2007) 30-50. doi: 10.1016/j.drup.2007.02.004.

[12] W.D. Wilson, F.A. Tanious, A. Mathis, D. Tevis, J.E. Hall, D.W. Boykin, Antiparasitic compounds that target DNA. Biochimie. 90 (2008) 999-1014. doi: 10.1016/j.biochi.2008.02.017.

[13] J. Mosqueda, A. Olvera-Ramirez, G. Aguilar-Tipacamu, G.J. Canto, Current advances in detection and treatment of babesiosis. Curr. Med. Chem. 19 (2012) 1504-1518. doi: 10.2174/092986712799828355.

[14] J.H. Ansede, M. Anbazhagan, R. Brun, J.D. Easterbrook, J.E. Hall, D.W. Boykin, O-alkoxyamidine prodrugs of furamidine: in vitro transport and microsomal metabolism as indicators of in vivo efficacy in a mouse model of Trypanosoma brucei rhodesiense infection. J. Med. Chem. 47 (2004) 43354338. doi: 10.1021/jm030604o.

[15] M.F. Paine, M. Z. Wang, C.N. Generaux, D.W. Boykin, W.D. Wilson, H.P. De Koning, C.A. Olson, G. Pohlig, C.Burr, R. Brun, G.A. Murilla, J.K. Thuita, M.P. Barrett, R.R. Tidwell, Diamidines for human African trypanosomiasis. Curr. Opin. Invest. Drugs. 11 (2010) 876-883.

[16] W.D. Wilson, B. Nguyen, F.A. Tanious, A. Mathis, J.E. Hall, C.E. Stephens, D.W. Boykin, Dications that target the DNA minor groove: compound design and preparation, DNA interactions, cellular distribution and biological activity. Curr. Med. Chem. Anticancer. Agents. 5 (2005) 389-408. doi: $10.2174 / 1568011054222319$.

[17] M.N.C. Soeiro, K. Werbovetz, D.W. Boykin, W.D. Wilson, M.Z. Wang, A. Hemphill, Novel amidines and analogues as promising agents against intracellular parasites: a systematic review. Parasitol. 140 (2013) 929-951. doi: 10.1017/S0031182013000292. 
[18] G. Yang, G. Choi, J.H. No, Antileishmanial mechanism of diamidines involves targeting kinetoplasts. Antimicrob. Agents Chemother. 60 (2016) 6828-6836. doi: 10.1128/AAC.01129-16.

[19] A.M. Mathis, A.S. Bridges, M.A. Ismail, A. Kumar, I. Francesconi, M. Anbazhagan, Q. Hu, F.A. Tanious, T. Wenzler, J. Saulter, W.D. Wilson, R. Brun, D.W. Boykin, R.T. Tidwell, J.E. Hall, Diphenyl furans and aza analogs: effects of structural modification on in vitro activity, DNA binding, and accumulation and distribution in trypanosomes. Antimicrob. Agents Chemother. 51 (2007) 2801-2810. doi. 10.1128/AAC.00005-07.

[20] H.P. de Koning, Ever-increasing complexities of diamidine and arsenical crossresistance in African trypanosomes. Trends Parasitol. 24 (2008) 345-349. doi: 10.1016/j.pt.2008.04.006.

[21] C.P. Ward, P.E. Wong, R.J. Burchmore, H.P. de Koning, M.P. Barrett, Trypanocidal furamidine analogues: influence of pyridine nitrogens on trypanocidal activity, transport kinetics, and resistance patterns. Antimicrob. Agents Chemother. 55 (2011) 2352-2361. doi: 10.1128/AAC.01551-10.

[22] S. Melchor, D. de la Torre, C. Vázquez, Z. González-Chávez, L. Yépez-Mulia, R. Nieto-Meneses, R. Jasso, E. Saavedra, F. Hernández-Luis, Synthesis and biological evaluation of 2-methyl-1H-benzimidazole-5-carbohydrazides derivatives as modifiers of redox homeostasis of Trypanosoma cruzi. Bioorg. Med. Chem. Lett. 27 (2017) 3403-3407. doi: 10.1016/j.bmcl.2017.06.013

[23] I. Pauli, L.G. Ferreira, M.L. de Souza, G. Oliva, R.S. Ferreira, M.A. Dessoy, B.W. Slafer, L.C. Dias, A.D. Andricopulo, Molecular modeling and structureactivity relationships for a series of benzimidazole derivatives as cruzain inhibitors. Future Med. Chem. 9 (2017) 641-657. doi: 10.4155/fmc-2016-0236.

[24] J.M. Velázquez-López, A. Hernández-Campos, L. Yépez-Mulia, A. TéllezValencia, P. Flores-Carrillo, R. Nieto-Meneses, R. Castillo, Synthesis and trypanocidal activity of novel benzimidazole derivatives. Bioorg. Med. Chem. Lett. 26 (2016) 4377-4381. doi: 10.1016/j.bmcl.2015.08.018.

[25] M. Boiani, L. Boiani, A. Merlino, P. Hernández, A. Chidichimo, J.J. Cazzulo, H. Cerecetto, M. González, Second generation of 2H-benzimidazole 1, 3-dioxide 
derivatives as anti-trypanosomatid agents: Synthesis, biological evaluation, and mode of action studies. Eur. J. Med. Chem. 44 (2009) 4426-4433. doi: 10.1016/j.ejmech.2009.06.014.

[26] C. Karaaslan, M. Kaiser, R. Brun, H. Göker, Synthesis and potent antiprotozoal activity of mono/di amidino 2-anilinobenzimidazoles versus Plasmodium falciparum and Trypanosoma brucei rhodesiense. Bioorg. Med. Chem. 24 (2016) 4038-4044. doi: 10.1016/j.bmc.2016.06.047.

[27] A.A. Farahat, C. Bennett-Vaughn, E.M. Mineva, A. Kumar, T. Wenzler, R. Brun, Y. Liu, W.D. Wilson, D.W. Boykin, Synthesis, DNA binding and antitrypanosomal activity of benzimidazole analogues of DAPI. Bioorg. Med. Chem. Lett. 26 (2016) 5907-5910. doi: 10.1016/j.bmcl.2016.11.006.

[28] M.A. Ismail, R. Brun, T. Wenzler, F.A. Tanious, W.D. Wilson, D.W. Boykin, Dicationic biphenyl benzimidazole derivatives as antiprotozoal agents. Bioorg. Med. Chem. 12 (2004) 5405-5413. doi: 10.1016/j.bmc.2004.07.056.

[29] M.A. Ismail, A. Batista-Parra, Y. Miao, W.D. Wilson, T. Wenzler, R. Brun, D.W. Boykin, Dicationic near-linear biphenyl benzimidazole derivatives as DNA-targeted antiprotozoal agents. Bioorg. Med. Chem. 13 (2005) 6718-6726. doi: 10.1016/j.bmc.2005.07.024.

[30] S.A. Bakunov, S.M. Bakunova, T. Wenzler, M. Ghebru, K.A. Werbovetz, R. Brun, R.R. Tidwell, Synthesis and antiprotozoal activity of cationic 1,4diphenyl-1H-1,2,3-triazoles. J. Med. Chem. 53 (2009) 254-272. doi: $10.1021 / \mathrm{jm} 901178 \mathrm{~d}$.

[31] L. Krstulović, I. Stolić, M. Jukić, T. Opačak-Bernardi, K. Starčević, M. Bajić, L. Glavaš-Obrovac, New quinoline-arylamidine hybrids: Synthesis, DNA/RNA binding and antitumor activity. Eur. J. Med. Chem. 137 (2017) 196-210. doi: 10.1016/j.ejmech.2017.05.054.

[32] I. Stolić, H.Č. Paljetak, M. Perić, M. Matijašić, V. Stepanić, D. Verbanac, M. Bajić, Synthesis and structure-activity relationship of amidine derivatives of 3,4-ethylenedioxythiophene as novel antibacterial agents. Eur. J. Med. Chem. 90 (2015) 68-81. doi: 10.1016/j.ejmech.2014.11.003. 
[33] A. Bistrović, L. Krstulović, I. Stolić, D. Drenjančević, J. Talapko, J. M. Kelly, M. Bajić, S. Raić-Malić, Synthesis, DNA/RNA-binding, antibacterial and antiprotozoal activities of novel 5-amidinobenzimidazoles. J. Enzyme Inhib. Med. Chem. 33 (2018) 271-285. doi: 10.1080/14756366.2017.1414807.

[34] R.M.B.M. Girard, M. Crispim, I. Stolić, F.S. Damasceno, M.S. da Silva, E.M. Furusho Pral, M.C. Elias, M. Bajić, A.M. Silber, An aromatic diamidine that targets kinetoplast DNA, impairs the cell cycle in Trypanosoma cruzi, and diminishes Trypomastigote release from infected mammalian cell. Antimicrob. Agents Chemother. 60 (2016) 5867-5877. doi: 10.1128/AAC.01595-15.

[35] M. Mascal, E.B. Nikitin, Dramatic advancements in the saccharide to 5-(chloromethyl) furfural conversion reaction. Chem. Sus. Chem. 2 (2009) 859861 doi: $10.002 /$ cssc. 200900136.

[36] W. Gao, Y. Li, Z. Xiang, K. Chen, R. Yang, D.S. Argyropoulos, Efficient onepot synthesis of 5-chloromethylfurfural (CMF) from carbohydrates in mild biphasic systems. Molecules 18 (2013) 7675-7685. doi: 10.3390/molecules 18077675 .

[37] M. Hranjec, K. Starcevic, B. Zamola, S. Mutak, M. Derek, G. KarminskiZamola, New amidino-benzimidazolyl derivatives of tylosin and desmycosin. J. Antibiot. 55 (2002) 308-314. doi: 10.7164/antibiotics.55.308.

[38] S.U. Rehman, T. Sarwar, M.A. Husain, H.M. Ishqi, M. Tabish, Studying noncovalent drug-DNA interactions. Arch. Biochem. Biophys. 576 (2015) 49-60. doi: 10.1016/j.abb.2015.03.024.

[39] M. Ganeshpandian, S. Ramakrishnan, M. Palaniandavar, E. Suresh, A. Riyasdeen, M.A. Akbarsha, Mixed ligand copper (II) complexes of 2,9dimethyl-1,10-phenanthroline: Tridentate $3 \mathrm{~N}$ primary ligands determine DNA binding and cleavage and cytotoxicity. J. Inorg. Biochem. 140 (2014) 202-212. doi: 10.1016/j.jinorgbio.2014.07.021.

[40] N. Shahabadi, S. Hadidi, Spectroscopic studies on the interaction of calf thymus DNA with the drug levetiracetam. Spectrochim. Acta Mol. Biomol. Spectrosc. 96 (2012) 278-283. doi: 10.1016/j.saa.2012.05.045. 
[41] W.D. Wilson, F.A. Tanious, M. Fernandez-Saiz, C.T. Rigl, Evaluation of drugnucleic acid interactions by thermal melting curves. Method. Mol. Biol. 90 (1997) 219-240. doi: 10.1385/0-89603-447-X:219.

[42] S. Alnabulsi, E. Santina, I. Russo, B. Hussein, M. Kadirvel, A. Chadwick, E.V. Bichenkova, R.A. Bryce, K. Nolan, C. Demonacos, I.J. Stratford, Nonsymmetrical furan-amidines as novel leads for the treatment of cancer and malaria. Eur. J. Med. Chem. 111 (2016) 33-45. doi: 10.1016/j.ejmech.2016.01.022

[43] Y. Liu, A. Kumar, D.W. Boykin, W.D.Wilson, Sequence and length dependent thermodynamic differences in heterocyclic diamidine interactions at AT base pairs in the DNA minor groove. Biophys. Chem. 131 (2007) 1-14. doi: 10.1016/j.bpc.2007.08.007.

[44] P. O'Sullivan, I. Rozas, Understanding the Guanidine-Like Cationic Moiety for Optimal Binding into the DNA Minor Groove. Chem. Med. Chem, 9 (2014) 2065-2073. doi: 10.1002/cmdc.201402264.

[45] D. Havrylyuk, B. Zimenkovsky, O. Karpenko, P. Grellier, R. Lesyk, Synthesis of pyrazoline-thiazolidinone hybrids with trypanocidal activity. Eur. J. Med. Chem. 85 (2014) 245-254. doi: 10.1016/j.ejmech.2014.07.103.

[46] L.M. Tumir, I. Crnolatac, T. Deligeorgiev, A. Vasilev, S. Kaloyanova, M. Grabar Branilović, S. Tomić, I. Piantanida, Kinetic differentiation between homo- and alternating AT-DNA by sterically restricted phosphonium dyes. Chem. Eur. J. 18 (2012) 3859-3864. doi: 10.1002/chem.201102968.

[47] R. Palchaudhuri, P.J. Hergenrother, DNA as a target for anticancer compounds: methods to determine the mode of binding and the mechanism of action. Curr. Opin. Biotechnol. 18 (20079 497-503. doi: 10.1016/j.copbio.2007.09.006.

[48] A. Anand, R.J. Naik, H.M. Revankar, M.V. Kulkarni, S.R. Dixit, S.D. Joshi, A click chemistry approach for the synthesis of mono and bis aryloxy linked coumarinyl triazoles as anti-tubercular agents. Eur. J. Med. Chem. 105 (2015) 194-207. doi: 10.1016/j.ejmech.2015.10.019.

[49] Q. Li, K. Han, J. Li, X. Jia, C. Li, Synthesis of dendrimer-functionalized pillar [5] arenes and their self-assembly to dimeric and trimeric 
complexes. Tetrahedron

Lett. 56

(2015)

$3826-3829$.

doi:

10.1016/j.tetlet.2015.04.078.

[50] I. Stolić, K. Mišković, A. Magdaleno, A.M. Silber, I. Piantanida, M. Bajić, L. Glavaš-Obrovac, Effect of 3, 4-ethylenedioxy-extension of thiophene core on the DNA/RNA binding properties and biological activity of bis benzimidazole amidines. Bioorg. Med. Chem. 17 (2009) 2544-2554. doi: 10.1016/j.bmc.2009.01.071.

[51] G. Scatchard, The attractions of proteins for small molecules and ions. Ann. N. Y. Acad. Sci. 51 (1949) 660-672. doi: 10.1111/j.1749-6632.1949.tb27297.x.

[52] J.D. McGhee, P.H. von Hippel, Theoretical aspects of DNA-protein interactions: co-operative and non-co-operative binding of large ligands to a one-dimensional homogeneous lattice. J. Mol. Biol. 86 (1974) 469-489. doi: 10.1016/00222836(74)90031-X.

[53] M.C. Taylor, M.D. Lewis, A. Fortes Francisco, S.R. Wilkinson, J.M. Kelly, The Trypanosoma cruzi vitamin $\mathrm{C}$ dependent peroxidase confers protection against oxidative stress but is not a determinant of virulence. PLoS Negl. Trop. Dis. 9 (4) (2015) e0003707. doi: 10.1371/journal.pntd.0003707.

[54] H.M. Berman, J. Westbrook, Z. Feng, G. Gilliland, T.N. Bhat, H. Weissig, I.N. Shindyalov, P.E. Bourne, The Protein Dana Bank, Nucleic Acid Res. 28 (2000) 235-242. doi: 10.1093/nar/28.1.235.

[55] H.R. Drew, R.M. Wing, T. Takano, C. Broka, S. Tanaka, K. Itakura, R.E. Dickerson, Structure of a B-DNA dodecamer: conformation and dynamics. Proc. Natl. Acad. Sci. USA. 78 (1981) 2179-2183. doi: 10.1073/pnas.78.4.2179.

[56] H. Ehara, T. Yokoyama, H. Shigematsu, S. Yokoyama, M. Shirouzu, S.I. Sekine, Structure of the complete elongation complex of RNA polymerase II with basal factors. Science 357 (2017) 921-924. doi: 10.1126/science.aan8552.

[57] J. Maier, C. Martinez, K. Kasavajhala, L. Wickstrom, K. Hauser, C. Simmerling, ff14SB: improving the accuracy of protein side chain and backbone parameters from ff99SB. J. Chem. Theory Comput. 11 (2015) 3696-3713. doi: 10.1021/acs.jctc. 5 b00255. 
[58] J. Wang, R.M. Wolf, J. Caldwell, P.A. Kollman, D.A. Case, Development and testing of a general amber force field. J. Comput. Chem. 25 (2004) 1157-1174. doi: $10.1002 /$ jcc. 20035 .

[59] D.A. Case, R.M. Betz, D.S. Cerutti, T.E. Cheatham, T. Darden, R.E. Duke, T.J. Giese, H. Gohlke, A.W. Goetz, N. Homeyer, S. Izadi, P. Janowski, J. Kaus, A. Kovalenko, T.S. Lee, S. LeGrand, P. Li, C. Lin, T. Luchko, R. Luo, B. Madej, D. Mermelstein, K.M. Merz, G. Monard, H. Nguyen, H.T. Nguyen, I. Omelyan, A. Onufriev, D.R. Roe, A. Roitberg, C. Sagui, C. Simmerling, W.M. BotelloSmith, J. Swails, R.C. Walker, J. Wang, R.M. Wolf, X. Wu, L. Xiao and P.A. Kollman, AMBER16, 2016, University of California, San Francisco.

[60] J.P. Ryckaert, G. Ciccotti, H.J.C. Berendsen, Numerical integration of the cartesian equations of motion of a system with constraints: molecular dynamics of n-alkanes. J. Comput. Phys. 23(1997) 327-341. doi: 10.1016/00219991(77)90098-5.

[61] R.J. Loncharich, B.R. Brooks; R.W. Pastor, Langevin dynamics of peptides: The frictional dependence of isomerization rates of $\mathrm{N}$-acetylalanyl- $\mathrm{N}^{\prime}$-methylamide. Biopolymers 32 (1992) 523-535. doi: 10.1002/bip.360320508.

[62] H.J.C. Berendsen, J.P.M. Postma, W.F. van Gunsteren, A. DiNola, J.R. Haak, Molecular dynamics with coupling to an external bath J. Chem. Phys. 81 (1984) 3684-3690. doi: 10.1063/1.448118. 